Ximena J. Nelson ${ }^{1 *}$

$5 \quad$ Natasha Fijn ${ }^{2}$

6

$7 \quad{ }^{1}$ School of Biological Sciences, University of Canterbury, Private Bag 4800, Christchurch, New

8 Zealand.

$9{ }^{2}$ School of Archaeology and Anthropology, The Australian National University, Canberra, 10 Australia.

*Correspondence: Ximena Nelson, School of Biological Sciences, University of Canterbury,

13 Private Bag 4800, Christchurch, New Zealand.

14 Email: ximena.nelson@canterbury.ac.nz

15 Phone: 64-3-3642987 extn 4050

16 Fax: 64-3-3642590

19 Abstract

20 In this essay we outline how video-related technology can be used as a tool for studying

21 animal behaviour. We review particular aspects of novel, innovative animal behaviour

22 uploaded by the general public via video-based media on the internet (using YouTube ${ }^{\mathrm{Tm}}$ as a

23 specific example). The behaviour of animals, particularly the play behaviour focussed on here,

24 is viewed by huge audiences. Within this essay we focussed on three different kinds of media

25 clips: 1) interspecies play between dogs and a range of different species; 2) object play in

26 horses; and 3) animal responses to stimuli presented on iPads, iPods and iPhones. We argue 
27 that the use of video is a good means of capturing uncommon or previously unknown

28 behaviour, providing evidence that these behaviours occur. Furthermore, some of the

29 behaviours featured on YouTube provide valuable insights for future directions in animal

30 behaviour research. If we also take this opportunity to convey our knowledge to a public that

31 seems to be fundamentally interested in animal behaviour, this is a good means of bridging

32 the gap between knowledge amongst an academic few and the general public.

33

34 Keywords: citizen science, online resources, 'people power', crowdsourcing, internet,

35 playback studies, preliminary testing, opportunistic observation, YouTube 
37 Wildlife films and natural history documentaries are immensely popular with the general public. Entire distribution networks are dedicated to the broadcasting of wildlife programmes (Bousé 2000). Significantly, one of the main features of such programmes is the behaviour of other animals, which is evidently fascinating to humans. There is, however, a lack of engagement with wildlife in relation to research in animal behaviour. In contrast observational filmmaking may form an integral part of the interpretation and presentation of research findings within visual anthropology (MacDougall 1998, 2001, 2006 ; Grimshaw

Within the popular 2011 Attenborough series The Frozen Planet, the BBC Natural History Unit filmed a rarely observed behaviour not just once, but on multiple occasions. The sequences show in unprecedented detail how orca (Orcinus orca) work together to create waves to wash seals off ice floes in order to capture them in the water (1, Table 1). Another instance of novel behaviour, captured for BBC Wildlife on One (Kea- smartest parrots? 2004), is that of kea (Nestor notabilis), a threatened species of mountain parrot renowned for its cognitive ability, opportunistically opening large wheelie bins $(2$, Table, 1$)$. We know this sequence involved novel foraging behaviour in wild animals, as it was filmed by one of the authors (NF) and the learned behaviour was subsequently published (Gajdon et al. 2006). Nevertheless, there are limitations in terms of the use of wildlife documentaries within

60 elements can be introduced which are not chronologically or sequentially correct and have 61 often been altered considerably through editing in postproduction (e.g., 3, Table, 1). 
original unedited material, or 'raw footage'. Post-production editing is perhaps one of the reasons why footage from wildlife films has not been used as a tool for interpretation and analysis within academia. We therefore chose to exclude wildlife documentaries from our analysis, and focus instead upon the relatively new medium of video-sharing on the internet. Unlike wildlife films, we suggest that footage uploaded by the public onto the internet is more amenable to analysis, primarily because it is easier to establish whether a situation is 'real' through the absence of professional postproduction editing.

We bring to this essay an interdisciplinary approach to the use of visual media, with combined backgrounds in animal behaviour, particularly visual cognition; human-animal studies; and visual anthropology. Video is now commonly used as a means of presentation in science, as key examples in lectures or conferences, but this is primarily as an illustrative tool, rather than as a means for exploring further research, or as an integral part of the presentation of results. In this essay we advocate the use of video beyond just an illustrative example and instead suggest that viewing raw footage posted on the internet can act as a springboard for further investigation.

\section{Citizen science}

Scientific projects have been developed to engage the public as participants in the collection of data through the use of 'crowdsourcing' methods - outsourcing a job to an undefined group of people. This 'citizen science' approach has been advocated for use by ecologists and could be of great use amongst animal behaviour researchers (Dickinson et al. 2010; for links to projects in ecology and evolution see Silvertown 2009). One such example of citizen science research is a project on the migration of the monarch butterfly, Danaus plexippus. Since 2005, the migration pattern of this species has been largely tracked by an ever-increasing number of participants in the Journey North program (Howard \& Davis 2009, 2011; 4, Table 1). 
Resources freely available on the internet are being increasingly used in behavioural

89 studies. For example, Google Earth $^{\text {TM }}$ is now often used to pinpoint study sites and satellite imagery has been used to explore the use of magnetic cues for orientation by ruminants

91 (Begall et al. 2008; Hert et al. 2011). Another example of the use of satellite maps is a National

92 Geographic-sponsored blog site that encourages interested participants to scan maps for potential archaeological digs in Mongolia, thereby actively involving these citizen scientists in the scientific process. The archaeologists on the project target key sites that are tagged by multiple viewers and then visit these sites for assessment (5, Table 1; on 16 Oct 2012 the site stated that 21,181 people were 'online explorers' and 841,454 images/titles had been processed).

With cameras that can easily be held in the palm of the hand, video technology is now readily accessible. It is now possible to inexpensively obtain wearable high-definition waterproof cameras (such as those made by GoPro, Woodman Labs, USA), which are often used to film extreme sports such as snowboarding or base-jumping, from the point of view of the participant. People have found novel uses for these cameras, such as strapping them to the heads or bodies of animals (e.g., longhorn bull, 6, Table 1). Such footage taken from the point of view of the animal could provide a new perspective on social interactions. For example, the online clip "Beautiful Day at the Dog Park" (7, Table 1) depicts an edited sequence of the social interactions of dogs in a park. This example gives a good indication of how shots can be played in extreme slow motion to provide a new perspective on social interactions.

\section{Using social media as a tool}

110 Our premise for using YouTube ${ }^{\text {Tm }}$ as a tool for searching for animal behaviour is based on the 111 notion that the probability of capturing any given behaviour is dramatically increased when 112 the number of people obtaining the footage is not restricted to academics but is widened to 113 citizen scientists. This form of recording animal behaviour involves anyone that has a video 
114 camera, still camera, or mobile phone, and is willing to post clips onto the internet. One of the 115 goals of this essay is to offer ways in which we can observe and gather spontaneous examples 116 of interesting, rare, or unusual behaviour in animals and utilize this for qualitative means.

117 While these media clips do not adhere to a particular methodology, we can nevertheless 118 consider this as opportunistic observation useful for preliminary hypothesis testing. 119 YouTube was launched in 2005 and has continued to grow at an immense rate ever since. 120 As early as mid-2006, YouTube had made over 100 million videos available to the public, with 121 a daily upload of 65,000 videos (8, Table 1). By 2012, hundreds of millions of users upload 48 122 h of video footage every day. We invite researchers in animal behaviour to use this immense 123 database as a research tool.

124 We have focussed on YouTube, rather than other social media on the internet, as YouTube 125 often features videos that have not been edited together into a sequence (examples in 126 Appendices 1-3). Another video-sharing website, Vimeo ${ }^{\mathrm{TM}}$, generally has videos that contain 127 sequences edited together as some form of narrative, as this site targets amateur and 128 professional filmmakers, rather than the general public. Edited sequences from wildlife or 129 natural history film productions, news media, or other documentary production companies 130 that have subsequently been uploaded onto YouTube were excluded from our animal 131 behaviour analyses, as the images are often manipulated in postproduction before 132 distribution to the public.

We judged whether the behaviour on the video clips was 'real' or 'fake' by introducing 134 parameters designed to exclude the manipulation of images in postproduction (the 135 anthropologist Michael Wesch $(2008,2009)$ addresses the aspect of 'fakery', or in his words, 136 the 'authenticity crisis' in relation to vlogs (video blogs) on YouTube). Most video clips 137 uploaded to YouTube by the public consist of very few shots (often a single shot) of raw 138 footage that has been minimally edited, if at all. In order to avoid elements of manipulation we 139 excluded clips that had visibly altered images through the use of editing software. When we 
came across multiple independent instances of video segments featuring similar contexts, such as object play with balls by horses, we could be confident that this kind of play activity spontaneously occurs in horses.

We defined that the YouTube clip must: 1) Have no obvious postproduction manipulation of the image itself. Titles, subtitles, and music were acceptable, as these elements were unlikely to influence the interpretation of the image itself and could be ignored for our purposes; 2) Consist of one main scene with up to four shots per clip. Single shot clips were ideal, as this meant that the footage had not been edited together as a narrative-based sequence; 3) Be derived from the original source, not downloaded and appropriated from elsewhere; 4) Be independent; we ensured that a different animal was always observed by careful scrutiny of the animal's morphology and surroundings and any further details given by the person uploading the video, such as the pet's name; 5) Have minimal or no human manipulation of the animals' behaviour, nor any indication that the animal may have been trained to perform the behaviour. If there was any verbal encouragement from behind the camera, this was noted (see 'human influence' in Appendix 1).

We accepted that some form of human influence was inevitable within the YouTube clips, as it required a human to be filming from behind the camera. It is likely that animals would need to be habituated to human presence for behaviour to occur within reasonable proximity to a camera. Hence, we did not rule out instances when the person behind the camera spoke in a general manner, as most of the featured animals were zoo animals, domestic pets, or companion animals habituated to human vocalisations. In wildlife programmes behaviour is often caught using powerful telephoto lenses (although this distorts the image and can make it hard for the viewer to judge actual sizes or distances). Within the clips we reviewed, the only instances where the animals may have not perceived the presence of humans was when the video was shot from behind a window. 
167 Both authors have separately observed the notably playful kea (Diamond \& Bond 2004) repeatedly sliding down the icy roof of a mountain hut, therefore, we thought it significant to find a Russian video of a crow sliding down an icy roof using a plastic lid as a tool (9, Table 1). Similarly, a member of the public filmed an adult kea rolling a snowball (10, Table 1); although we have independently observed similar innovative behaviour (stone rolling and tossing) while conducting fieldwork on kea, we have not witnessed the unusual behaviour of snowball rolling. The value of videos of this kind is straightforward: a single record captured on video is evidence that the behaviour does in fact occur. Consequently, we focussed our online investigation on examples of 'play' behaviour because play is relatively understudied, often difficult to observe and thus quantify, and is inherently interesting to a large audience. This interest is clear based on the number of times some of these clips have been viewed. For example, the sliding crow clip (uploaded on 9 Jan 2012) had been viewed 670,884 times within six months. Additionally, multiple versions of this clip had been made, each reaching large numbers of viewers (e.g., one re-post, with an English title and keywords, had 761,225 viewings on 26 June 2012). Other instances of novel behaviour on YouTube include two clips of young foxes jumping on trampolines (11, Table 1). Consisting of a single shot with little background noise and no obvious intervention on the part of the person filming, this particular clip is a good example of what we have in mind and was uploaded), but the scope of footage featuring novel play behaviour on YouTube. human animals (for details, including links to the URLs, see Appendices 1-3): 1) Interspecies play in dogs (dogs playing with a wide variety of different species); 2) Object play, with a focus on horses playing with objects; and 3) Animal responses to iPads, iPods and iPhones 191 (henceforth: "iPads"). We use the latter to illustrate how we can use YouTube to assess 
methodology by extrapolating important aspects of visual processing from the responses of different species to stimuli presented on iPads. These topics are discussed as inspiration for further research, and not as a definitive quantitative analysis of the subject area. In all cases, the sequence of clips we reviewed were the first search results presented (excluding further uploads made from the original source) in relation to the keywords chosen for the search topic.

\section{Interspecies play behaviour}

There have been many studies concerning dog-human interspecies play (Mitchell \& Thompson 1990; Rooney et al. 2000, 2001; Rooney \& Bradshaw 2002, 2006), but play between dogs and other species has been little examined. Play between dogs and species other than humans does occur and YouTube is excellent for revealing spontaneous instances of these play bouts. When it became clear that dogs featured particularly heavily in clips depicting animals engaged in interspecies interactions (e.g., 'parrot and play', 'foxes and play'), we searched for keywords amongst specific kinds of animals that featured in play with dogs (e.g., 'dog and deer', 'dog and racoon', 'dog and bear', see Appendix 1).

Bekoff and Allen (1997) avoid strict functional definitions of play behaviour, as they argue that such definitions are limiting to analysis, and propose instead to observe and analyse on the basis of an intuitive understanding of play relying on particular signal behaviours, such as the stereotyped 'play bow' in dogs (Bekoff 1977, 1995). The bow can be used both as a guide for the other play 'mate' (or the viewer of a video clip) that an individual is communicating "I want to play"; or that the dog wants to maintain play, in other words "I still want to play". Canids also use what Bekoff (2001) calls 'self-handicapping', where a play behaviour is used as a compromise, such as not forcefully biting a play mate, but instead mouthing softly. We used a similar approach to our analysis of dogs engaging in interspecies 
217 play within the video clips and relied on reciprocal gestures, and particularly the 'play bow', 218 as signals that the two individuals were playing. Humans are inevitably present in all of the clips, but one of our parameters was that the humans were not considerably influencing, manipulating or changing the animals' interactions. We noted whether the interaction was between 'domestic' or 'wild' animals, but found that most were in the domestic category, as they were often nurtured by and habituated to humans and therefore the dog would have spent time in close proximity with the other animal (see wild/domestic column in Appendix 1).

Play behaviour was inventive and variable across the different clips relating to interspecies play. It was evident that the type of play was dependent upon the animal species

227 with which the dog engaged in play: with deer, the play was primarily oriented toward pawing, jumping, or chasing (e.g., 15, Table 1); with horses and cattle it was more oriented toward object play; with racoons, bears and foxes it tended to consist of mouthing and wrestling; while play with different species of parrot involved prodding and probing one another (see Appendix 1).

We noted that interspecies play between dogs and other species was often initiated by the dog. That dogs often tended to initiate play through the medium of objects suggests that

234 the play may have been exhibited through the participants' mutual neophilia in relation to objects. Neophilia and object play are evidently related phenomena, and may also be related to an animal's propensity to engage in interspecies play. Cetaceans, for example, are known to engage in object play and a recent report based on opportunistic observations demonstrates that humpback whales (Megaptera novaeangliae) will engage in play with bottlenose dolphins 239 (Deakos et al. 2010). This report is based on two observations off the coast of the Hawaiian 240 islands, but this sample size could be increased with the engagement of citizen science and 241 posts to YouTube as evidence. 
A well-known cliché is that dogs are 'man's best friend'. From the remarkable range of

243 species with whom dogs are spontaneously playing in online clips (involving ox, alpaca,

244 racoon, cat, fox, horse, squirrel, duckling, pig, monkey, lion, tiger, dolphin, shark, deer and

245 sheep and a number of species of corvid, parrot, and bear), one could conclude that dogs are

246 not particularly anthropocentric or even canine-centric in relation to play bouts- they appear

247 to play with any species that are willing to reciprocate.

\section{Object play in horses}

250 When it became clear which animals featured particularly heavily in clips of animals engaged in object play, we searched for keywords amongst specific kinds of animals and objects, in this case focussing on horses playing with balls (keyword search terms: 'horse and ball', 'horse playing and ball'), which were often, but not restricted to, inflated rubber balls (see Appendix 2).

Foals and young horses are known to engage in repeated bouts of object play and this could explain anecdotal accounts of tool-use by adult equids (see Crowell-Davis et al. 1987). There were two main kinds of object that initiated extended play bouts in horses within the 258 YouTube clips: small, coloured balls with a handle that could be gripped by the teeth, and larger coloured balls with no handle, often used by humans for exercise purposes. The two kinds of ball resulted in quite different object play behaviour, as the small ball could be picked up, shaken and dropped or tossed on the ground, while the larger ball was large enough to lean on and horses often exhibited a 'resting rear': belly on top of the ball with fore and hind legs on opposite sides (Appendix 2).

Using YouTube as a 'bench-test' for the analysis of object play in horses provided a 265 clear indication that inflated balls elicit a wide range of play behaviour, as seen in object play with dogs (see above). We observed all of McDonnell and Poulin's (2002) categories of 'object play' across the video clips, such as: 'nibble', 'sniff/lick', 'mouth', 'chew', 'pick up', 'shake', 
'carry', 'drop or toss', 'pull', 'paw', 'kick up', ‘to and from', 'circle', and 'resting rear'. McDonnell

269 and Poulin (2002) note that the frequency and the duration of play bouts are stimulated by

270 novel stimuli, such as encounters with novel objects.

Of note is that both dogs (see above) and horses were prone to play with objects. This

272 behaviour has been suggested as a possible reason why dogs have been successfully

273 domesticated (Kaulfuß \& Mills 2008). The examples of object play among young horses on

274 YouTube suggest that engagement with novel objects may also have contributed to the facility

275 with which these animals have become domesticated by humans. This leads to the more

276 general hypothesis that some form of neophilia, playfulness, or capacity to play with objects

277 may be traits that facilitate domestication or render animals amenable to training by humans.

278 While this idea is speculation on our behalf, we suggest that these sorts of hypotheses can be

279 explored in more detail with the aid of clips posted on YouTube, coupled with a survey of the

280 literature, and of course, where possible, rigorous hypothesis-testing.

These types of searches may also provide researchers investigating applied animal

282 behaviour and animal welfare with further ideas for environmental enrichment and may be

283 relevant to research projects involving cognition, development, learning or problem solving in

284 horses or other animals. When applied to wild animals, it is evident that play behaviour is

285 rarely observed in close proximity, and as such difficult to investigate in a quantitative

286 manner, resulting in the reliance of opportunistic observations to document its scope. Citizen

287 scientists posting clips on YouTube are a good means of obtaining evidence of such rare

288 behaviour.

\section{Animal responses to iPads}

291 Lizards (Ord et al. 2002; van Dyk et al. 2007; Nelson et al. 2010), some birds (Nelson et al.

292 2008; Smith et al. 2009), and jumping spiders (Harland \& Jackson 2002), among others, are

293 known to respond to video stimuli or to 3D computer animation in a similar manner to how 
294 they would respond to the equivalent real stimulus. These methods (particularly 3D 295 animation) allow us, for example, to explore the relevance of temporal patterns (e.g. van Dyk 296 et al. 2007), or the spatial structure of a display (e.g., Peters 2008), in eliciting different 297 responses by receivers. On the other hand, several species fail to respond to video or 298 animation (reviewed in Woo \& Rieucau 2011), seemingly having visual systems incompatible 299 with the presentation of video playback. A search through clips available on YouTube 300 identifies those species for which methods using computer animation or video technology are 301 likely to be more fruitful. We tabulated all instances of animals responding to iPads, iPods or 302 iPhones, noting details of the behaviour of the animal (Appendix 3). Keyword searches were 303 for "iPad", "iPhone" or "iPod" (generically referred to as 'iPad') and the animal in question (e.g., 304 "cat").

305 As a consequence of their diversity, the visual systems of some animals may have 306 characteristics that enable their bearers to be perceptually 'fooled' by stimuli presented on 307 monitors or screens; for example, evoking clear predatory or play responses, while little 308 response is evoked in other groups. While it is beyond the scope of this essay to provide a 309 detailed description of the visual systems of the animals featured in YouTube clips (primates, 310 cats, dogs, parrots, chameleons, dragon lizards, toads and geckos), some general information 311 is described below, and is summarised and referenced in Table 2. Humans have very good spatial acuity, but even our ability to extract detailed 313 information from a scene is outdone by some birds and primates (Table 2). Nevertheless, 314 animals for which visual acuity is poor compared to our own, such as cats and possibly toads 315 and lizards were highly responsive to stimuli on iPads. However, frog and toad vision is 316 adapted to detect moving prey, rather than for sampling with high spatial acuity (Ewert 2004), 317 and the importance of motion vision is also apparent in lizards (Ord et al. 2002; Nelson et al. 318 2010). 
An animal's temporal resolution can be determined by measuring the highest

320 frequency at which a flickering light source is seen as continuous (critical flicker fusion

321 frequency, CFF). Human CFF is $60 \mathrm{~Hz}$ (Woodhouse \& Barlow 1985), and it is on this basis that 322 monitor 'refresh rates' are based. Animals with higher CFF might therefore perceive video 323 presented on a conventional monitor (e.g., cathode ray tubes) as a strobe-like sequence of 324 images. Previous studies had difficulty in eliciting realistic responses to televised images in 325 hens (e.g., D’Eath \& Dawkins 1996; Patterson-Kane et al. 1997), but the CFF of chickens is 326 higher than our own (Lisney et al. 2011) so these methods may have been unsuitable. Modern 327 LCD monitors flicker at high rates $(120-240 \mathrm{~Hz})$ and chickens respond well to video stimuli 328 when presented in high definition and on LCD screens (e.g., Nelson et al. 2008; Smith et al. 329 2009; see also Watanabe \& Troje 2006).

Despite having acuity comparable to cats, dogs appeared unresponsive to the visual 331 element of the stimuli (Appendix 3). To some extent, their relatively high CFF (Table 2) helps explain their traditional lack of response to TV monitors (Pongrácz et al. 2003). Apparent stimulus size may also play a role, although audio was also used in examples using realistically sized stimuli, and 'real' stimuli always elicited the best responses (Pongrácz et al. 2003; Faragó et al. 2010). In contrast, a cat may lap 'milk' from an image of a real-size cup of milk presented on an iPad (12, Table 1).

The responses observed here showed clear-cut differences, with cats and reptiles being considerably more responsive to the stimuli presented on iPads than the other animals featured on YouTube. This fact is now exploited by developers of 'apps', with dozens of iPad applications specifically designed for felines. All of these involve a stimulus likely to elicit play 341 and/or predatory behaviour (usually a moving 'fish', 'mouse', or even 'laser' dots). Games designed to encourage cats to 'fish' for goldfish moving in a pond are clearly related to real world situations. Cats, for example, have been filmed skidding on frozen ponds as they 344 attempt to 'fish' for live fish swimming below the surface (13 \& 14, Table 1$)$. 
The most responsive species featured on YouTube suggest that high resolving power is

not necessary to elicit responses to stimuli on iPads, yet these species tend to have a CFF similar to our own. Advances in LCD technology may widen the number of species for which video playback is tractable. While the potential inability to perceive depth cues from a screen (Zeil 2000) may account for the lack of response in some species, there was no evidence that different mechanisms of depth perception were affecting responses, suggesting that multiple mechanisms of depth judgements (Table 2) are reliably 'fooled' by stimuli on two-dimensional screens.

"Humans, including human experimenters, "see" (and probably hear and feel) logical relations within stimuli that are not necessarily "there" for other species" (Lea et al. 2006, p. 254). This also applies the other way around. Even when other species have a sensory world not dissimilar to our own, it does not follow that we share the same experience, because we do not necessarily operate using the same 'logic', or because the salient features that make objects discernable varies between species (e.g., Nelson \& Jackson 2012). Conversely, it is noteworthy how often the features we 'attend' to are the same ones that animals - as different to us as jumping spiders - 'attend' to (Nelson \& Jackson 2006b). Indeed, from our analysis of animals responding to iPads, it is surprising how 'plastic' different perceptions and visual systems can be when interpreting these images.

The potential difficulties that arise regarding the use of playback technology as an experimental tool may lead to considerable time designing experiments which may often fail simply because the animals do not respond. This is where searches within YouTube can be helpful, as it allows us, using a large sample size that increases daily, to make preliminary assessments of what type of animal might be tractable for work using video stimuli.

\section{Assessing the popularity of animal behaviour clips on YouTube}


370 When the material in clips does not engage with the audience, they do not feature heavily on

371 YouTube, being seldom viewed, if at all. Conversely, if the public engages with the material,

372 clips rapidly 'go viral' and are viewed by millions of people (e.g., 16, Table 1). Based on this

373 knowledge, we searched the keywords "true crime full episodes" to determine public

374 engagement with a completely different but undoubtedly popular topic, based on the

375 television airtime featuring this genre (Jermyn 2007). We looked at how often the first 30

376 listings that appeared on the search were viewed (only considering clips that were $>40 \mathrm{~min}$

377 in length). Similarly, we used the keyword search "wildlife documentaries full length" (also >

$37840 \mathrm{~min}$ ) as a comparison with crime, and with the three different kinds of 'play' searches we 379 conducted.

380 An overview of the number of "views" of both crime and wildlife documentaries

381 testifies to the notion that the audience viewing these programs is very large indeed (Table 3).

382 Of note is that while the minimum number of views for crime shows, and particularly for

383 wildlife documentaries, is considerably larger than YouTube 'play' clips, the maximum

384 number of views for our play searches was often orders of magnitude higher (Table 3). One

385 might expect that horses playing with objects, or animals playing with iPads, would engage

386 with a much more restricted audience than highly publicised, big budget wildlife or crime

387 series, but they are in fact viewed by larger numbers of people and gain a similar (or greater)

388 number of 'likes' (Table 3). This suggests that the content of our searches was more affective

389 to the YouTube audience than big budget wildlife and crime documentaries. These large

390 viewing numbers also demonstrate that displaying behaviour using YouTube as a visual

391 medium is an excellent avenue to report or illustrate findings in the field of animal behaviour,

392 in addition to its potential for further observation and research.

394 Conclusion 
Many academic disciplines use anecdotes to develop research projects that ultimately produce reliable data (Bekoff 2000, 2006). As Bekoff (2006, p. 50) points out “...anecdotes are central to the study of behavior as they are to much of science. As we accumulate more and more stories about behavior we develop a solid database that can be used to stimulate further empirical research, and yes, additional stories. The plural of anecdote is data". With a video camera capturing an event, or multiple independent instances, the visual evidence immediately adds more weight than a textual account of the behaviour in question. With the increased availability of 'ready to capture' video acquisition tools across the general public, the possibility of capturing evidence of rare animal behaviour has increased manifold, and if the video is then uploaded onto the internet, viewing of the behaviour is readily accessible. White (2006, p. 3) aptly describes the material on YouTube as "scraps, detritus, driftwood: but some of it is also treasure". With a change of thinking within the sciences we can make the most of this new phenomenon and extract the occasional rare gem in the form of a behavioural event that is captured on camera. YouTube presents a vast resource, which can be explored for useful preliminary information, and provides large sample sizes, adding

411 iPads, we could rapidly determine the differences in responses between the different groups, 412 with some, such as cats and reptiles, emerging as clear candidates for video playback studies. 413 Others, such as dogs and primates, seem less tractable for video playback studies, as their 414 responses often seemed to be primarily based on contrast changes or sound (Appendix 3). In 415 addition to finding that some animals are much more likely to respond to 2D visual stimuli 416 than others, by determining the type of response we could also hazard an educated guess as 417 to the actual aspect of the stimulus that is being responded to (Appendix 3). It should be noted that the use of YouTube as data should be treated with caution, as 419 images and sounds can readily be manipulated in postproduction, much as wildlife films are 420 manipulated for a popular audience. Thus the line between reality and fakery, documentary 
421 and drama, and science and populism can become blurred. We advise searching on YouTube

422 according to the parameters we have suggested, particularly focussing on raw footage that is 423 comprised of a single shot with minimal levels of postproduction manipulation, and excluding 424 those that have been considerably altered.

425 Video has the potential to be used to a far greater extent in the observation of 426 behaviour beyond that of more structured experimental settings. The aim is to use YouTube 427 as a means of observation, in other words toward qualitative, rather than more quantitative 428 aspects of research. The results of such research could be presented according to filmmaking 429 techniques used in observational-style filmmaking (Fijn 2012), or integrated into a project 430 involving the active inclusion of citizen scientists (e.g., Silvertown 2009; Cooper et al. 2010). The use of video as a research tool, followed by subsequent posts onto the internet, has 432 the capacity to genuinely engage the public in science, and particularly in the study of animal 433 behaviour. This online involvement in the communication of animal play inevitably raises 434 public awareness of such behaviour. The public themselves become the researchers and the 435 communicators. Furthermore, the notion that, as academics, we can benefit from uploads 436 posted by the general public makes this a watershed for two-way benefits between science 437 and the public. Greater rapport between an academic few and the wider public should be a 438 good thing.

440 Acknowledgements

441 We thank M. Bekoff and two anonymous reviewers for constructive feedback on the 442 manuscript and to the public for sharing their wonderful clips online. 
Aho, A. C. 1997. The visual acuity of the frog (Rana pipiens). Journal of Comparative Physiology A, 180, 19-24.

\section{Barbour, H. R., Archer, M. A., Hart, N. S., Thomas, N., Dunlop, S. A., Beazley, L. D. \& Shand,} J. 2002. Retinal characteristics of the ornate dragon lizard, Ctenophorus ornatus. Journal of Comparative Neurology, 450, 334-344.

Begall, S., Cerveny, J., Neef, J., Vojtech, O. \& Burda, H. 2008. Magnetic alignment in grazing and resting cattle and deer. Proceedings of the National Academy of Sciences, 105, 1345113455.

Bekoff, M. 1977. Social communication in canids: evidence for the evolution of a stereotyped mammalian display. Science, 197, 1097-1099.

Bekoff, M. 1995. Play signals as punctuation: the structure of social play in canids. Behaviour, $132,419-429$.

Bekoff, M. 2000. Animal emotions: exploring passionate natures. BioScience, 50, 861-870.

Bekoff, M. 2001. Social play behaviour: cooperation, fairness, trust, and the evolution of morality. Journal of Consciousness Studies, 8, 81-90.

Bekoff, M. 2006. Animal passions and beastly virtues: cognitive ethology as the unifying science for understanding the subjective, emotional, empathetic and moral lives of animals. Human Ecology Forum. Zygon, 41, 71-104.

Bekoff, M. \& Allen, C. 1997. Intentional communication and social play: how and why animals negotiate and agree to play. In: Animal Play: Evolutionary, Comparative and Ecological Perspectives (Ed. by M. Bekoff \& J. A. Byers), pp. 97-114. Cambridge \& New York: Cambridge University Press.

Blake, R. 1988. Cat spatial vision. Trends in Neurosciences, 11, 78-83.

Bousé, D. 2000. Wildlife Films. Philadelphia: University of Pennsylvania Press. 
471 Bowmaker, J. K., Loew, E. L. \& Ott, M. 2005. The cone photoreceptors and visual pigments of chameleons. Journal of Comparative Physiology A, 191, 925-932.

473 Clark, D. L. \& Uetz, G. W. 1990. Video image recognition by the jumping spider, Maevia fusion in dogs. Physiology \& Behavior, 45, 1087-1092.

Collin, S. P. 1999. Behavioural ecology and retinal cell topography. In: Adaptive Mechanisms in inclemens (Araneae: Salticidae). Animal Behaviour, 40, 884-891.

Coile, D. C., Pollitz, C. H. \& Smith, J. C. 1989. Behavioral determination of critical flicker the Ecology of Vision (Ed. by S. Archer, M. B. Djamgoz, E. Loew, J. C. Partridge \& S. Vallerga), pp. 509-535. Dordrecht: Kluwer.

Cooper, S., Khatib, F., Treuille, A., Barbero, E., Lee, J., Beenen, M., Leaver-Fay, A., Baker, D., Popović, Z. \& Foldit players. 2010. Predicting protein structures with a multiplayer online game Nature, 466, 756-760

Crowell-Davis, S. L., Houpt, K. A. \& Kane, L. 1987. Play development in welsh pony (Equus caballus) foals. Applied Animal Behaviour Science, 18, 119-131.

D'Eath, R. B. \& Dawkins, M. S. 1996. Laying hens do not discriminate between video images of conspecifics. Animal Behaviour, 52, 903-912.

Deakos, M. H., Branstetter, B. K., Mazzuca, L., Fertyl D. \& Mobley, J. R. Jr. 2010. Two unusual interactions between a bottlenose dolphin (Tursiops truncatus) and a humpback whale (Megaptera novaeangliae) in Hawaiian Waters. Aquatic Mammals, 36, 121-128.

Demery, Z. P., Chappell, J. \& Martin, G. R. 2011. Vision, touch and object manipulation in Senegal parrots Poicephalus senegalus Proceedings of the Royal Society B, 278, 36873693.

Diamond, J. \& Bond, A. B. 2004. Social play in kaka (Nestor meridionalis) with comparisons to kea (Nestor notabilis). Behaviour, 141, 777-798.

Dickinson, J. L., Zuckerberg, B. \& Bonter, D. N. 2010. Citizen science as an ecological research tool: Challenges and benefits. Annual Review of Ecology, Evolution and 
Systematics, 41, 149-172.

498 Ewert, J. P. 2004. Motion perception shapes the visual world of amphibians. In: Complex

Worlds from Simpler Nervous Systems (Ed. by F. R. Prete), pp, 117-160. Cambridge, Massachusetts: MIT Press.

Faragó, T., Pongrácz, P, Miklósi, A., Huber, L., Virányi, Z. \& Range, F. 2010. Dogs' expectation about signalers' body size by virtue of their growls. PLoS ONE, 5, e15175. doi:10.1371/journal.pone.0015175.

Fijn, N. 2007. Filming the significant other: human and non-human. Asia Pacific Journal of Anthropology, 8, 297-307.

Fijn, N. 2012. A multispecies etho-ethnographic approach to filmmaking. The Humanities Research Journal, 18, 71-88.

Gajdon, G. K., Fijn, N. \& Huber, L. 2006. Limited spread of innovation in a wild parrot, the kea (Nestor notabilis). Animal Cognition, 9: 173-181.

Galoch Z. \& Bischof, H. J. 2007. Behavioural responses to video playbacks by zebra finch males. Behavioral Processes, 74, 21-26.

Grimshaw, A. 2001. The ethnographer's eye: ways of seeing in anthropology. Cambridge: Cambridge University Press.

Harland, D. P. \& Jackson, R. R. 2002. Influence of cues from the anterior medial eyes of virtual prey on Portia fimbriata, an araneophagic jumping spider. Journal of Experimental Biology, 205, 1861-1868.

Hert, J., Jelinek, L., Pekarek, L. \& Pavlicek, A. 2011. No alignment of cattle along geomagnetic field lines found. Journal of Comparative Physiology A, 197, 677-682.

House, D. 1989. Depth perception in frogs and toads: a study in neural computing. Lecture Notes in Biomathematics, Vol. 80. New York: Springer-Verlag.

Howard, E. \& Davis, A. K. 2009. The fall migration flyways of monarch butterflies in eastern North America revealed by citizen scientists. Journal of Insect Conservation, 13, 279-286. 
523 Howard, E. \& Davis, A. K. 2011. A simple numerical index for assessing the spring migration

524

525

526

527

528

529

530

531

532 of monarch butterflies using data from journey north, a citizen-science program. Journal of the Lepidopterists' Society, 65, 267-270.

Jacobs, G. H. 2009. Evolution of colour vision in mammals. Philosophical Transactions of the Royal Society B, 364, 2957-2967.

Jermyn, D. 2007. Crime watching: Investigating real crime TV. London: I. B. Tauris.

Jones, M. P., Pierce, K. E. \& Ward, D. 2007. Avian vision: A review of form and function with special consideration to birds of prey. Journal of Exotic Pet Medicine, 16, 69-87.

Kaulfuß, P. \& Mills, D. S. 2008. Neophilia in domestic dogs (Canis familiaris) and its implication for studies of dog cognition. Animal Cognition, 11, 553-556.

Lea, S. E. G., Goto, K., Osthaus, B. \& Ryan, C. M. E. 2006. The logic of the stimulus. Animal Cognition, 9, 247-256.

Lind, 0. \&, Kelber, A. 2011. The spatial tuning of achromatic and chromatic vision in budgerigars. Journal of Vision, 11, 2. doi: 10.1167/11.7.2.

Lisney, T. J, Rubene, D., Rózsa, J., Løvlie, H., Håstad, O. \& Ödeen, A. 2011. Behavioural assessment of flicker fusion frequency in chicken Gallus gallus domesticus. Vision Research, 51, 1324-1332.

MacDougall, D. 1998. Transcultural Cinema. Princeton, New Jersey: Princeton University Press.

MacDougall, D. 2001. Renewing ethnographic film: is digital video changing the genre? Anthropology Today, 17, 15-21.

MacDougall, D. 2006. The Corporeal Image. Princeton, New Jersey: Princeton University Press.

McDonnell, S. M. \& Poulin, A. 2002. Equid play ethogram. Applied Animal Behaviour Science, 78, 263-290.

Miller, P. E. \& Murphy, C. J. 1995. Vision in dogs. Journal of the American Veterinary Medical Association, 207, 1623-1634. 
Mitchell, R. W. \& Thompson, N. S. 1990. The effects of familiarity on dog-human play. Anthrozoos, 4, 24-43.

Mullen. P. \& Pohland, G. 2008. Studies on UV reflection in feathers of some 1000 bird species: Are UV peaks in feathers correlated with violet-sensitive and ultravioletsensitive cones? Ibis, 150, 59-68.

Neitz, J., Geist, T. \& Jacobs, G. H. 1989. Color vision in the dog. Visual Neuroscience, 3, 119125.

Nelson, X. J. \& Jackson, R. R. 2006a. A predator from East Africa that chooses malaria vectors as preferred prey. PLoS ONE, 1, e132. doi:10.1371/journal.pone.0000132.

Nelson, X. J. \& Jackson, R. R. 2006b. Vision-based innate aversion to ants and ant mimics. Behavioral Ecology, 17, 676-681.

Nelson, X. J. \& Jackson, R. R. 2012. The discerning predator: decision rules underlying prey classification by a mosquito-eating jumping spider. Journal of Experimental Biology, 215, $2255-2261$.

Nelson, X. J., Wilson, D. R. \& Evans, C. S. 2008. Behavioral syndromes in stable social groups: An artifact of external constraints? Ethology, 114, 1154-1165.

Nelson, X. J., Garnett, D. T. \& Evans, C. S. 2010. Receiver psychology and the design of the deceptive caudal luring signal of the death adder. Animal Behaviour, 79, 555-561.

Nowak, L. M., \& Green, D. G. 1983. Flicker fusion characteristics of rod photoreceptors in the toad. Vision Research, 23, 845-849.

Ord, T. J., Peters, R. A., Evans, C. S. \& Taylor, A. J. 2002. Digital video playback and visual communication in lizards. Animal Behaviour, 63, 879-890.

Ott, M., Schaeffel, F., \& Kirmse, W. 1998. Binocular vision and accommodation in preycatching chameleons. Journal of Comparative Physiology A, 182, 319-330.

Ott, M., Ostheim, J. \& Sherbrooke, W. C. 2004. Prey snapping and visual distance estimation in Texas horned lizards, Phrynosoma cornutum. Journal of Experimental Biology, 207, 
3067-3072.

Patterson-Kane, E., Nicol, C. J., Foster, Y. M. \& Temple, W. 1997. Limited perception of video images by domestic hens. Animal Behaviour, 53, 951-963.

Pepperberg, I. M., Gardiner, L. I., \& Luttrell, L. J. 1999. Limited contextual vocal learning in the grey parrot (Psittacus erithacus): The effect of interactive co-viewers on videotaped instruction. Journal of Comparative Psychology, 113, 158-172.

Peters, R. A. 2008. Environmental motion delays the detection of movement-based signals. Biology Letters, 4, 2-5.

Pongrácz, P. Miklósi, A. Dóka, A. \& Csányi. 2003. Successful application of video-projected human images for signalling to dogs. Ethology, 109, 809-821.

Pretterer, G., Bubna-Littitz, H., Windischbauer, G., Gabler, C. \& Grielbel U. 2004. Brightness discrimination in the dog. Journal of Vision, 4, 241-249.

Ringo, J., Wolbarsht, M. L., Wagner, H. G., Crocker, R., \& Amthor, F. 1977. Trichromatic Vision in the Cat. Science, 198, 753-755.

Rooney, N. J. \& Bradshaw, J. W. S. 2002. An experimental study of the effects of play upon the dog-human relationship. Applied Animal Behaviour Science, 75, 161-176.

Rooney, N. J. \& Bradshaw, J. W. S. 2006. Social cognition in the domestic dog: behaviour of spectators towards participants in interspecific games. Animal Behaviour, 72, 343-352.

Rooney, N. J., Robinson, I. H. \& Bradshaw, J. W. S. 2000. A comparison of dog-dog and doghuman play behaviour. Applied Animal Behaviour Science, 66, 235-248.

Rooney, N. J., Robinson, I. H. \& Bradshaw, J. W. S. 2001. Do dogs respond to play signals given by humans? Animal Behaviour, 61, 715-722.

Shumake, S. A., Smith, J. C. \& Taylor, H. L. 1968. Critical fusion frequency in rhesus monkeys. Psychological Record, 18, 537-542.

Silvertown, J. 2009. A new dawn for citizen science. Trends in Ecology and Evolution, 24, 467471. 
601 Smith, C. L., Van Dyk, D. A., Taylor, P. W. \& Evans, C. S. 2009. On the function of an enigmatic ornament: wattles increase the conspicuousness of visual displays in male fowl. Animal Behaviour, 78, 1433-1440.

Van Dyk, D. A., Taylor, A. J. \& Evans, C. S. 2007. Assessment of repeated displays: a test of possible mechanisms. Journal of Experimental Biology, 210, 3027-3035.

Veilleux, C. C. \& Kirk, C. E. 2009. Visual Acuity in the Cathemeral Strepsirrhine Eulemur macaco flavifrons. American Journal of Primatology, 71, 1-10.

Watanabe, S. \& Troje, N. F. 2006. Towards a "virtual pigeon": A new technique for investigating avian social perception. Animal Cognition, 9, 271-279.

Wesch, M. 2008. An anthropological introduction to YouTube. http://www.youtube.com/watch?v=TPAO-lZ4 hU, Library of Congress, accessed $29 / 6 / 2012$

Wesch, M. 2009. YouTube and you: Experiences of self-awareness in the context of collapse of the recording webcam. Explorations in Media Ecology, 8, 19-34.

White, R. 2006. Treasure tube. Film Quarterly, 60, 3.

Woo, K. L. \& Rieucau, G. 2011. From dummies to animations: a review of computer-animated stimuli used in animal behavior studies. Behavioral Ecology and Sociobiology, 65, 16711685.

Woo, K. L., Burke, D. \& Peters, R. A. 2009. Motion sensitivity of the Jacky dragon, Amphibolurus muricatus: Random-dot kinematograms reveal the importance of motion noise for signal detection. Animal Behaviour, 77, 307-315.

Woodhouse, J. M. \& Barlow, H. B. 1985. Spatial and temporal resolution and analysis. In The Senses (Ed. by H. B. Barlow \& J. D. Mollon), pp 133-164. Cambridge: Cambridge University Press.

Zeil, J. 2000. Depth cues, behavioural context, and natural illumination: some potential limitations of video playback techniques. Acta Ethologica, 3, 39-48. 
Table 1. YouTube links to clips referred to in the text.

\begin{tabular}{llc}
\hline Clip number & \multicolumn{1}{c}{ Link } & Date accessed \\
\hline 1 & http://www.youtube.com/watch?v=hPge_0lea3o & 3 Oct 2012 \\
2 & http://www.youtube.com/watch?v=bxoCuRuHlt8 & 3 Oct 2012 \\
3 & http://www.youtube.com/watch?v=dZxepRApAhg & 30 Nov 2012 \\
4 & http://www.learner.org/jnorth/ & 27 June 2012 \\
5 & http://exploration.nationalgeographic.com/ & 27 June 2012 \\
6 & http://www.youtube.com/watch?v=_hB8LHS6j30\&feature=player_embedded & 29 June 2012 \\
7 & http://www.youtube.com/watch?v=rxBS1E0KZQU & 29 June 2012 \\
8 & https://www.youtube.com/t/press_timeline & 29 June 2012 \\
9 & http://www.youtube.com/watch?v=6uXiAe7Oc-I & 16 Feb 2012 \\
10 & http://www.youtube.com/watch?v=gil4q7FVRC8 & 27 Feb 2012 \\
11 & http://www.youtube.com/watch?v=c8xJtH6UcQY\&feature=related & 26 June 2012 \\
12 & http://www.youtube.com/watch?v=3QQVpddOalo, & 12 April 2012 \\
\hline
\end{tabular}


28 Feb 2012 
632 Table 2. Summary information on the visual systems of the different groups featured in YouTube clips 'playing' with iPads.

\begin{tabular}{|c|c|c|c|c|c|}
\hline Group & $\begin{array}{l}\text { Spatial acuity } \\
\text { (cycles/degree) }\end{array}$ & Colour vision & $\begin{array}{l}\text { CFF (Hz) } \\
\text { Rod/cone }\end{array}$ & $\begin{array}{l}\text { Depth } \\
\text { judgement }\end{array}$ & References \\
\hline Humans & $30-60$ & Trichromatic & $18 / 60$ & Stereoscopic & Woodhouse \& Barlow 1985 \\
\hline $\begin{array}{l}\text { Other } \\
\text { primates }\end{array}$ & Varied & Varied & $20 / 90$ & Stereoscopic & $\begin{array}{l}\text { Shumake et al. 1968; Jacobs 2009; Veilleux } \\
\text { \& Kirk } 2009\end{array}$ \\
\hline Dogs & $5-11$ & Dichromatic & $50 / 90$ & Stereoscopic & $\begin{array}{l}\text { Coile et al. 1989; Neitz et al. 1989; Miller \& } \\
\text { Murphy 1995; Pretterer et al. } 2004\end{array}$ \\
\hline Cats & $6-8$ & Trichromatic & $20 / 60$ & $\begin{array}{l}\text { Stereoscopic at } \\
\text { close distances }\end{array}$ & Ringo et al. 1977; Blake 1988 \\
\hline Toads & Possibly 3 & $\begin{array}{l}\text { Dichromatic (possibly } \\
\text { trichromatic) }\end{array}$ & 6/Unknown & Stereoscopic & $\begin{array}{l}\text { Nowak \& Green 1983; House 1989; Aho } \\
\text { 1997; Ewert } 2004\end{array}$ \\
\hline Chameleons & Unknown & Possibly tetrachromatic & Unknown & Accommodation & $\begin{array}{l}\text { Ott et al. 1998; Collin 1999; Bowmaker et } \\
\text { al. } 2005\end{array}$ \\
\hline $\begin{array}{l}\text { Lizards } \\
\text { (dragons) }\end{array}$ & Unknown & $\begin{array}{l}\text { Trichromatic (possibly } \\
\text { tetrachromatic) }\end{array}$ & Unknown & Accommodation & $\begin{array}{l}\text { Barbour et al. 2002; Ott et al. 2004; Woo } \\
\text { et al. } 2009\end{array}$ \\
\hline Parrots & 10 & Tetrachromatic & $40 / 70$ & $\begin{array}{l}\text { Stereoscopic at } \\
\text { close distances }\end{array}$ & $\begin{array}{l}\text { Jones et al. 2007; Mullen \& Pohland 2008; } \\
\text { Demery et al. 2011; Lisney et al. 2011; } \\
\text { Lind \& Kelber } 2011\end{array}$ \\
\hline
\end{tabular}


636 Table 3. Descriptive statistics of the number of views and 'likes' per month on YouTube for each of the five assessed categories.

\begin{tabular}{|c|c|c|c|c|c|c|}
\hline & $\begin{array}{c}\text { Descriptive } \\
\text { statistics }\end{array}$ & iPad & $\begin{array}{c}\text { Horse object } \\
\text { play }\end{array}$ & $\begin{array}{c}\text { Interspecies } \\
\text { play }\end{array}$ & $\begin{array}{c}\text { True crime } \\
\text { documentaries }\end{array}$ & $\begin{array}{c}\text { Wildlife } \\
\text { documentaries }\end{array}$ \\
\hline \multirow[t]{6}{*}{ Number of views } & Minimum & 8.1 & 0.3 & 4.1 & 213.0 & 334.7 \\
\hline & 25\% Percentile & 62.92 & 27.15 & 421.2 & 689.2 & 2,980 \\
\hline & Median & 222.2 & 251.0 & 2,976 & 1,469 & 4,383 \\
\hline & 75\% Percentile & 2,784 & 1,176 & 10,952 & 3,151 & 8,067 \\
\hline & Maximum & $2,042,939$ & 41,725 & 136,025 & 8,165 & 61,028 \\
\hline & $\mathrm{N}$ & 116 & 29 & 41 & 30 & 20 \\
\hline \multirow[t]{5}{*}{ Number of "likes" } & Minimum & 0.0 & 0.0 & 0.0 & 0.0004 & 0.0019 \\
\hline & 25\% Percentile & 0.0016 & 0.0013 & 0.0019 & 0.0012 & 0.0036 \\
\hline & Median & 0.0034 & 0.0022 & 0.0028 & 0.0016 & 0.0062 \\
\hline & 75\% Percentile & 0.0066 & 0.0042 & 0.0054 & 0.0024 & 0.0088 \\
\hline & Maximum & 0.1667 & 0.0407 & 0.0779 & 0.0070 & 0.0135 \\
\hline
\end{tabular}


640 Appendix 1. Instances of interspecies play behaviour with dogs on YouTube.

\begin{tabular}{|c|c|c|c|c|c|c|c|}
\hline Descriptor and animal & $\begin{array}{l}\text { Views/ } \\
\text { month }\end{array}$ & $\begin{array}{l}\text { Likes/ } \\
\text { month }\end{array}$ & $\begin{array}{c}\text { Dislikes } \\
\text { / } \\
\text { month }\end{array}$ & $\begin{array}{l}\text { no. of } \\
\text { shots }\end{array}$ & $\begin{array}{c}\text { Wild/ } \\
\text { domestic }\end{array}$ & $\begin{array}{c}\text { Human } \\
\text { influence }\end{array}$ & URL \\
\hline $\begin{array}{l}\text { Interspecies, object play, } \\
\text { crow and dog fetch ball }\end{array}$ & $30,975.69$ & 162.81 & 0.57 & 1 & $\mathrm{D}$ & $\mathrm{Y}$ & $\begin{array}{l}\text { http://www.youtube.com/watch?v=QqLU- } \\
\text { o7N7Kw\&feature=related }\end{array}$ \\
\hline $\begin{array}{l}\text { Interspecies, object play, } \\
\text { dog pulls magpie by object }\end{array}$ & 4.11 & 0.00 & 0.00 & 2 & $\mathrm{D}$ & $\mathrm{Y}$ & $\begin{array}{l}\text { http://www.youtube.com/watch?NR=1\&fe } \\
\text { ature=endscreen\&v=GMwrDefioMU }\end{array}$ \\
\hline $\begin{array}{l}\text { Interspecies, object play, } \\
\text { parrot offering dog food }\end{array}$ & $1,239.05$ & 2.71 & 0.07 & 1 & $\mathrm{D}$ & $\mathrm{N}$ & $\begin{array}{l}\text { http://www.youtube.com/watch?v=Fv9fxF } \\
\text { zDOw0\&feature=related }\end{array}$ \\
\hline $\begin{array}{l}\text { Interspecies, object play, } \\
\text { parrot and dog chewing }\end{array}$ & $2,975.71$ & 3.25 & 0.16 & 1 & $\mathrm{D}$ & $\mathrm{N}$ & $\begin{array}{l}\text { http://www.youtube.com/watch?v=PZ1rm } \\
\text { 4sGOz8\&feature=related }\end{array}$ \\
\hline paper & & & & & & & \\
\hline $\begin{array}{l}\text { Interspecies, object play, } \\
\text { dog and macaw grasping }\end{array}$ & $15,277.50$ & 79.40 & 0.90 & 1 & $\mathrm{D}$ & $\mathrm{N}$ & $\begin{array}{l}\text { http://www.youtube.com/watch?v=xjzX1p } \\
\text { uYq-4 }\end{array}$ \\
\hline
\end{tabular}




\begin{tabular}{|c|c|c|c|c|c|c|c|}
\hline stick & & & & & & & \\
\hline $\begin{array}{l}\text { Interspecies, object play, } \\
\text { ox and dog wrestle hose }\end{array}$ & 23.50 & 0.25 & 0.00 & 1 & $\mathrm{D}$ & $\mathrm{N}$ & $\begin{array}{l}\text { http://www.youtube.com/watch?v=fq6ZHg } \\
\text { 3ndzU }\end{array}$ \\
\hline Interspecies, object play, & & & & 1 & $\mathrm{D}$ & Y & http://www.youtube.com/watch?NR=1\&fe \\
\hline horse chasing dog to get & $14,701.43$ & 69.24 & 0.90 & & & & ature $=$ fvwp\&v $=$ UlsJHKLshVk \\
\hline object & & & & & & & \\
\hline Interspecies, object play, & & & & 1 & $\mathrm{D}$ & $\mathrm{N}$ & http://www.youtube.com/watch?v=UWGz5 \\
\hline dog and horse grasping & $3,312.00$ & 18.63 & 0.19 & & & & k80_XY\&feature=related \\
\hline object & & & & & & & \\
\hline Interspecies, object play, & & & & 1 & $\mathrm{D}$ & $\mathrm{N}$ & http://www.youtube.com/watch?v=fgVPV \\
\hline horse chasing dog from & $23,753.20$ & 163.93 & 0.87 & & & & WXuEoU\&feature=related \\
\hline ball & & & & & & & \\
\hline Interspecies, object play, & & & & 1 & $\mathrm{D}$ & $\mathrm{Y}$ & http://www.youtube.com/watch?v=GnZST \\
\hline dog and deer pawing and & $95,400.43$ & 180.25 & 8.64 & & & & kycovg \\
\hline wrestling & & & & & & & \\
\hline Interspecies play, dog play & 5262 & 035 & PO & 1 & $\mathrm{D}$ & $\mathrm{N}$ & http://www.youtube.com/watch?v=Ex80P \\
\hline bows, crow jumping & & & & & & & LOUTIM \\
\hline
\end{tabular}




\begin{tabular}{|c|c|c|c|c|c|c|c|}
\hline Interspecies play, dog & & & & 1 & $\mathrm{D}$ & $\mathrm{N}$ & http://www.youtube.com/watch?v=ficwZQ \\
\hline $\begin{array}{l}\text { nuzzling duckling, while } \\
\text { duckling probes }\end{array}$ & $136,025.07$ & 374.93 & 11.33 & & & & YmRLE \\
\hline Interspecies play, parrot & & & & 1 & $\mathrm{D}$ & Y & http://www.youtube.com/watch?v=- \\
\hline probing dog, dog jumps, & 205.26 & 0.68 & 0.00 & & & & oCkPOTRY5A \\
\hline play bows & & & & & & & \\
\hline Interspecies play, dog & & & & 1 & $\mathrm{D}$ & Y & http://www.youtube.com/watch?v=b70sL_ \\
\hline nipping, lorikeet probing & 944.65 & 2.00 & 0.00 & & & & mixnA\&feature=related \\
\hline with bill & & & & & & & \\
\hline Interspecies play, parrot & $2,229.12$ & 10.12 & 0.12 & 1 & $\mathrm{D}$ & $\mathrm{N}$ & \\
\hline probes while dog licks & & & & & & & 08fJI\&feature=related \\
\hline Interspecies play, parrot & 704.14 & 2.79 & 0.00 & 1 & $\mathrm{D}$ & $\mathrm{Y}$ & http://www.youtube.com/watch?v=yRzQu \\
\hline probes dog in play & & & & & & & W2sshk\&feature=related \\
\hline Interspecies play, alpaca & 175.29 & 0.39 & 0.00 & 1 & D & $\mathrm{N}$ & http://www.youtube.com/watch?v=eVXoaj \\
\hline chasing dog in circles & & & & & & & 3niU8\&feature=related \\
\hline Interspecies play, dog play & 860.83 & 1.26 & 0.00 & 1 & $\mathrm{D} / \mathrm{W} ?$ & Y & http://www.youtube.com/watch?v=N57CPl \\
\hline bows, chases, deer running & & & & & & & 9LArs \\
\hline
\end{tabular}




\begin{tabular}{|c|c|c|c|c|c|c|c|}
\hline in circle & & & & & & & \\
\hline $\begin{array}{l}\text { Interspecies play, deer } \\
\text { pawing and dog wrestling }\end{array}$ & $6,345.43$ & 10.83 & 0.73 & 1 & $\mathrm{D}$ & $\mathrm{N}$ & $\begin{array}{l}\text { http://www.youtube.com/watch?feature=e } \\
\text { ndscreen\&NR=1\&v=vxABe1PaLtU }\end{array}$ \\
\hline $\begin{array}{l}\text { Interspecies play, deer } \\
\text { jumping at dog }\end{array}$ & $6,105.59$ & 10.21 & 0.41 & 1 & $\mathrm{D}$ & $\mathrm{Y}$ & $\begin{array}{l}\text { http://www.youtube.com/watch?v=5K- } \\
\text { CTyvNE04\&feature=related }\end{array}$ \\
\hline Interspecies play, racoon & & & & 1 & $\mathrm{D}$ & $\mathrm{Y}$ & http://www.youtube.com/watch?v=M_ucrS \\
\hline and dog mouthing & 517.88 & 1.45 & 0.05 & & & & $\begin{array}{l}\text { DeuLI\&feature=results_main\&playnext=1\&l} \\
\text { ist=PL0FFBADBA8A21F519 }\end{array}$ \\
\hline Interspecies play, racoon & & & & 1 & $\mathrm{D}$ & $\mathrm{N}$ & http://www.youtube.com/watch?v=dz_L9z \\
\hline $\begin{array}{l}\text { exploring dog while dog } \\
\text { sitting }\end{array}$ & $1,806.67$ & 8.60 & 0.07 & & & & 09_s8\&feature=related \\
\hline $\begin{array}{l}\text { Interspecies play, racoon } \\
\text { and dog mouthing }\end{array}$ & $1,2917.61$ & 32.34 & 1.41 & 1 & $\mathrm{D}$ & $\mathrm{N}$ & $\begin{array}{l}\text { http://www.youtube.com/watch?v=eXcHK } \\
\text { Ntiz8M\&feature=related }\end{array}$ \\
\hline Interspecies play, racoon & & & & 1 & $\mathrm{D}$ & $\mathrm{Y}$ & http://www.youtube.com/watch?v=75hSke \\
\hline $\begin{array}{l}\text { and dog mouthing, dog } \\
\text { play bow }\end{array}$ & $6,160.96$ & 15.79 & 0.31 & & & & 3ujt0\&feature=related \\
\hline Interspecies play, dog and & $6,228.47$ & 9.40 & 0.20 & 1 & $\mathrm{D}(\mathrm{zoo})$ & Y & http://www.youtube.com/watch?v=rqLkd5 \\
\hline
\end{tabular}




\begin{tabular}{|c|c|c|c|c|c|c|c|}
\hline bear cub wrestle & & & & & & & Vs0aY\&feature=relmfu \\
\hline $\begin{array}{l}\text { Interspecies play, bear and } \\
\text { dog mouthing, chasing }\end{array}$ & $2,174.60$ & 8.64 & 0.08 & 1 & (institute) & $\mathrm{N}$. & $\begin{array}{l}\text { http://www.youtube.com/watch?v=z02650 } \\
\text { om8U4 }\end{array}$ \\
\hline $\begin{array}{l}\text { Interspecies play, bear and } \\
\text { dog mouthing }\end{array}$ & $5,807.22$ & 16.56 & 0.22 & 4 & $\mathrm{D} / \mathrm{W}$ & $\mathrm{N}$ & $\begin{array}{l}\text { http://www.youtube.com/watch?v=R8tZJP } \\
\text { CedB8 }\end{array}$ \\
\hline $\begin{array}{l}\text { Interspecies play, polar } \\
\text { bear jumping up at dog }\end{array}$ & 271.00 & 2.00 & 0.00 & 1 & $\begin{array}{l}\mathrm{D} / \mathrm{W} \\
\text { (zoo) }\end{array}$ & $\mathrm{Y}$ & $\begin{array}{l}\text { http://www.youtube.com/watch?v=Yko3h_ } \\
\text { 3l3ic }\end{array}$ \\
\hline $\begin{array}{l}\text { Interspecies play, dog and } \\
\text { foxes wrestle }\end{array}$ & $11,397.77$ & 67.19 & 0.75 & 1 & $\mathrm{D} / \mathrm{W}$ & $\mathrm{N}$ & $\begin{array}{l}\text { http://www.youtube.com/watch?v=tcn5haJ } \\
\text { pKAQ\&feature=related }\end{array}$ \\
\hline $\begin{array}{l}\text { Interspecies play, dog and } \\
\text { fox wrestle }\end{array}$ & 626.41 & 5.05 & 0.00 & 1 & $\mathrm{D}$ & $\mathrm{N}$ & $\begin{array}{l}\text { http://www.youtube.com/watch?v=JCqAXh } \\
\text { QqZXE }\end{array}$ \\
\hline $\begin{array}{l}\text { Interspecies play, lion } \\
\text { pounces on dog }\end{array}$ & 165.00 & 1.00 & 0.00 & 1 & $\begin{array}{l}\mathrm{D} / \mathrm{W} \\
\text { (zoo) }\end{array}$ & $\mathrm{Y}$ & $\begin{array}{l}\text { http://www.youtube.com/watch?v=0lCGdc } \\
\text { 07PiM\&feature=relmfu }\end{array}$ \\
\hline $\begin{array}{l}\text { Interspecies play, dogs } \\
\text { wrestling tiger }\end{array}$ & $93,743.64$ & 203.71 & 13.00 & 1 & $\mathrm{D}$ & $\mathrm{N}$ & $\begin{array}{l}\text { http://www.youtube.com/watch?feature=e } \\
\text { ndscreen\&NR=1\&v=igQRWZJklIo }\end{array}$ \\
\hline $\begin{array}{l}\text { Interspecies play, cat } \\
\text { pawing, dog play bows }\end{array}$ & 43.50 & 0.25 & 0.00 & 1 & $\mathrm{D}$ & Y & $\begin{array}{l}\text { http://www.youtube.com/watch?v=3cNtzg } \\
\text { TflnQ\&feature=related }\end{array}$ \\
\hline
\end{tabular}




\begin{tabular}{|c|c|c|c|c|c|c|c|}
\hline $\begin{array}{l}\text { Interspecies play, macaque } \\
\text { grasping at dog }\end{array}$ & $1,023.71$ & 1.00 & 0.06 & 3 & $\mathrm{D}$ & $\mathrm{N}$ & $\begin{array}{l}\text { http://www.youtube.com/watch?v=- } \\
\text { FrNwh_7F5w }\end{array}$ \\
\hline Interspecies play, monkey & & & & 1 & $\mathrm{D}$ & $\mathrm{N}$ & http://www.youtube.com/watch?v=jVpcx8 \\
\hline leaping, biting, dog & $3,978.23$ & 9.69 & 0.00 & & & & UMD0Y\&feature=related \\
\hline mouthing & & & & & & & \\
\hline $\begin{array}{l}\text { Interspecies play, dog } \\
\text { chasing dolphins }\end{array}$ & $13,550.33$ & 26.76 & 1.52 & 1 & $\mathrm{D} / \mathrm{W}$ & $\mathrm{Y}$ & $\begin{array}{l}\text { http://www.youtube.com/watch?v=FB8ITi } \\
\text { qwlw0\&feature=related }\end{array}$ \\
\hline $\begin{array}{l}\text { Interspecies play, dogs } \\
\text { chasing shark }\end{array}$ & 324.50 & 0.25 & 0.13 & 1 & $\mathrm{D} / \mathrm{W}$ & $\mathrm{Y}$ & $\begin{array}{l}\text { http://www.youtube.com/watch?v=- } \\
\text { ydMWxwXSG4 }\end{array}$ \\
\hline Interspecies play, dog & & & & 3 & $\mathrm{D} / \mathrm{W}$ & $\mathrm{N}$ & http://www.youtube.com/watch?v=22xigD \\
\hline $\begin{array}{l}\text { chasing, jumping at } \\
\text { squirrel in tree }\end{array}$ & $5,408.40$ & 13.00 & 0.10 & & & & Z9Qao \\
\hline $\begin{array}{l}\text { Interspecies play, piglet } \\
\text { butts dog, dog play bows }\end{array}$ & $4,433.22$ & 8.13 & 0.00 & 1 & $\mathrm{D}$ & $\mathrm{Y}$ & $\begin{array}{l}\text { http://www.youtube.com/watch?v=HNVOA } \\
\text { xRwH04 }\end{array}$ \\
\hline $\begin{array}{l}\text { Interspecies play, rabbit } \\
\text { jumping around dog, dog }\end{array}$ & $10,507.15$ & 38.45 & 1.55 & 1 & $\mathrm{D}$ & $\mathrm{N}$ & $\begin{array}{l}\text { http://www.youtube.com/watch?v=dhWpq } \\
\text { _G-6o\&feature=related }\end{array}$ \\
\hline paws and mouths & & & & & & & \\
\hline
\end{tabular}


Interspecies play, sheep

circling, dog jumping
154.00

641

642 
643 Appendix 2. Instances of novel object play behaviour by horses found on YouTube.

\begin{tabular}{|c|c|c|c|c|c|c|}
\hline Animal & Descriptor & $\begin{array}{l}\text { Views/ } \\
\text { month }\end{array}$ & $\begin{array}{l}\text { Likes/ } \\
\text { month }\end{array}$ & $\begin{array}{l}\text { Dislikes/ } \\
\text { month }\end{array}$ & $\begin{array}{l}\text { No. of } \\
\text { shots }\end{array}$ & URL \\
\hline $\begin{array}{l}\text { Horse } \\
\text { (young) }\end{array}$ & $\begin{array}{l}\text { Object (large ball) } \\
\text { play: resting rear, } \\
\text { circle, mouth, push, } \\
\text { kick up }\end{array}$ & $41,725.00$ & 230.30 & 5.75 & 1 & $\begin{array}{l}\text { http://www.youtube.com/watch?v=emxI- } \\
\text { nRGWBE\&feature=related }\end{array}$ \\
\hline Foal & $\begin{array}{l}\text { Object (large ball) } \\
\text { play: mouth, push }\end{array}$ & 362.54 & 0.62 & 0.00 & 1 & $\begin{array}{l}\text { http://www.youtube.com/watch?v=kVns0WDgAmU\&feat } \\
\text { ure=related }\end{array}$ \\
\hline Foal & $\begin{array}{l}\text { Object (large ball) } \\
\text { play: resting rear, } \\
\text { push, kick }\end{array}$ & 531.24 & 0.76 & 0.02 & 1 & $\begin{array}{l}\text { http://www.youtube.com/watch?feature=endscreen\&NR } \\
=1 \& \mathrm{v}=\mathrm{hCCauSjaBx0}\end{array}$ \\
\hline $\begin{array}{l}\text { Horse } \\
\text { (young) }\end{array}$ & $\begin{array}{l}\text { Object (large ball) } \\
\text { play: circle, push, } \\
\text { resting rear }\end{array}$ & $1,405.24$ & 1.78 & 0.00 & 2 & $\begin{array}{l}\text { http://www.youtube.com/watch?v=15G2iCYSWP8\&featu } \\
\text { re=related }\end{array}$ \\
\hline
\end{tabular}




\begin{tabular}{|c|c|c|c|c|c|c|}
\hline Horse (3 y) & $\begin{array}{l}\text { Object (large ball) } \\
\text { play: paw, resting } \\
\text { rear, push, pick up, } \\
\text { drop }\end{array}$ & $1,312.10$ & 2.82 & 0.00 & 1 & $\begin{array}{l}\text { http://www.youtube.com/watch?NR=1\&feature=endscre } \\
\text { en\&v=DPHOJngWZhg }\end{array}$ \\
\hline $\begin{array}{l}\text { Horse } \\
\text { (young) }\end{array}$ & $\begin{array}{l}\text { Object (large ball) } \\
\text { play: mouth, push, } \\
\text { kick, paw, circle }\end{array}$ & 889.80 & 5.80 & 0.04 & 1 & $\begin{array}{l}\text { http://www.youtube.com/watch?v=xDzG7ueQfWQ\&featu } \\
\text { re=related }\end{array}$ \\
\hline Foal & $\begin{array}{l}\text { Object (large ball) } \\
\text { play: resting rear, } \\
\text { kneel, push, gallops } \\
\text { away }\end{array}$ & 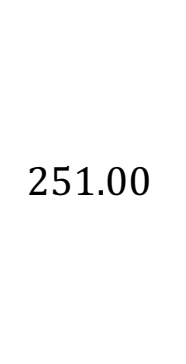 & 0.58 & . & 1 & $\begin{array}{l}\text { http://www.youtube.com/watch?v=2HemYttpjBI\&feature } \\
\text { =related }\end{array}$ \\
\hline Horse, dog & $\begin{array}{l}\text { Object (small hoop) } \\
\text { play, interspecies } \\
\text { play: pick up, shake }\end{array}$ & 690.21 & 3.18 & 0.03 & 2 & $\begin{array}{l}\text { http://www.youtube.com/watch?v=LbU30xiYyhg\&featur } \\
\text { e=fvwrel }\end{array}$ \\
\hline $\begin{array}{l}\text { Horse } \\
\text { (stallion }\end{array}$ & $\begin{array}{l}\text { Object (large ball) } \\
\text { play: pick up, rear, }\end{array}$ & $2,189.15$ & 6.05 & 0.05 & 1 & $\begin{array}{l}\text { http://www.youtube.com/watch?v=tuFSeh07RzI\&feature } \\
\text { =watch_response_rev }\end{array}$ \\
\hline colt) & toss & & & & & \\
\hline
\end{tabular}




\begin{tabular}{|c|c|c|c|c|c|c|}
\hline Horse $(3$ & Object (large ball) & & & & 1 & http://www.youtube.com/watch?v=2HCu_qeYJr8\&feature \\
\hline mo) & $\begin{array}{l}\text { play: push, circle, } \\
\text { gallops away }\end{array}$ & $1,039.42$ & 0.00 & 0.00 & & $=$ related \\
\hline Horse & $\begin{array}{l}\text { Object (marker cone } \\
\text { and balls) play: rear, } \\
\text { toss, push }\end{array}$ & 335.67 & 2.73 & 0.02 & 1 & $\begin{array}{l}\text { http://www.youtube.com/watch?v=mhOxhGYNq0Y\&feat } \\
\text { ure=related }\end{array}$ \\
\hline $\begin{array}{l}\text { Horse } \\
\text { (pony) }\end{array}$ & $\begin{array}{l}\text { Object (small ball) } \\
\text { play: pick up, toss, } \\
\text { shake, carry, drop, to } \\
\text { and from, circle }\end{array}$ & $3,059.41$ & 5.59 & 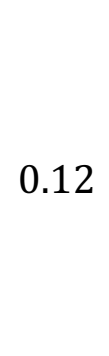 & 1 & http://www.youtube.com/watch?v=52UxyjnBQTI \\
\hline Horse & $\begin{array}{l}\text { Object (small ball) } \\
\text { play: roll, pick up, } \\
\text { shake }\end{array}$ & 0.28 & 0.00 & 0.00 & 1 & http://www.youtube.com/watch?v=cvq9PicoTrs \\
\hline $\begin{array}{l}\text { Donkey, } \\
\text { horse }\end{array}$ & $\begin{array}{l}\text { Object (small ball) } \\
\text { play, interspecies } \\
\text { play: pick up, rear, } \\
\text { kick up }\end{array}$ & 45.45 & 0.36 & 0.00 & 1 & http://www.youtube.com/watch?v=dKflVqS1buM \\
\hline
\end{tabular}




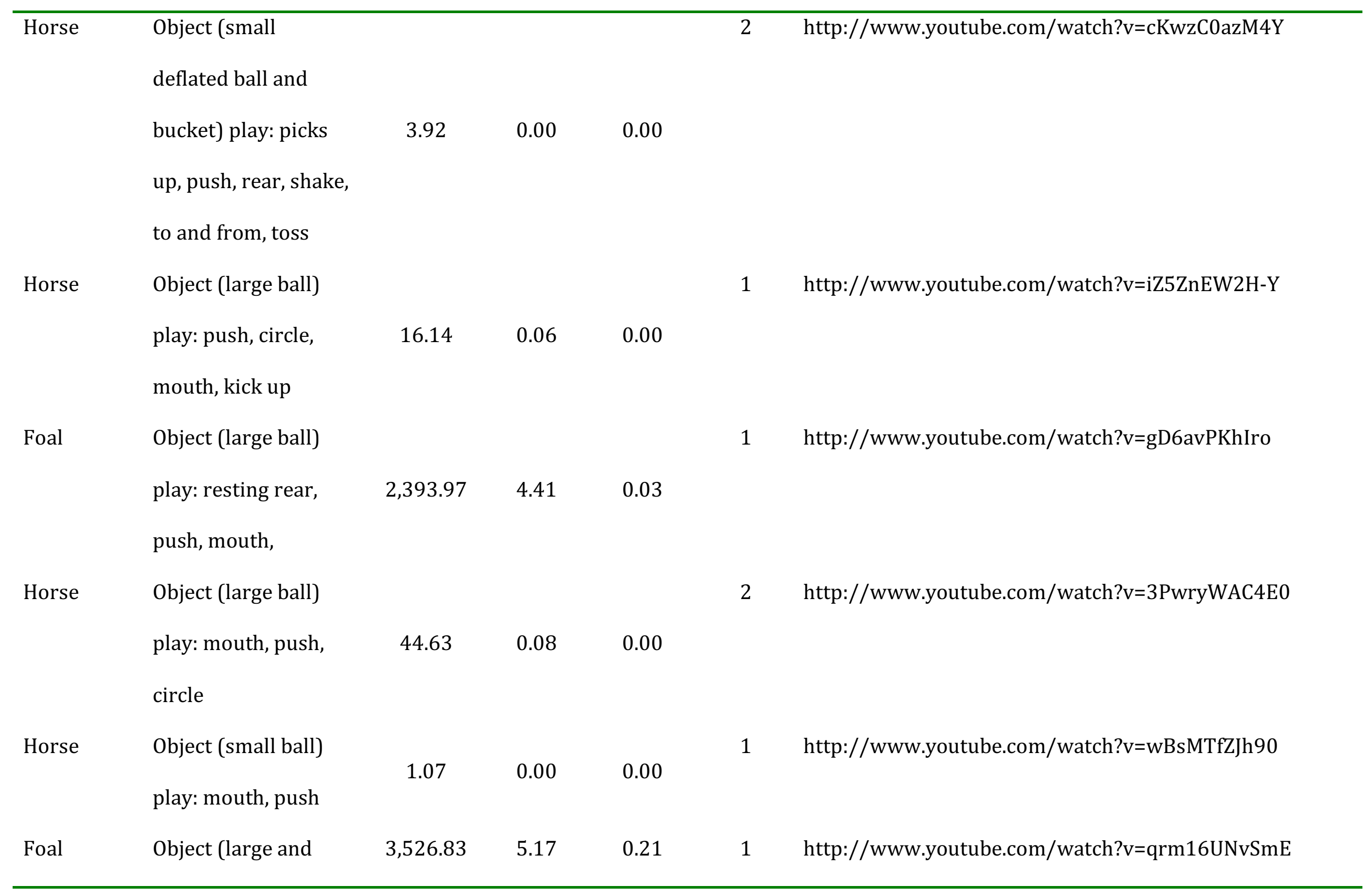


smaller ball) play:

pick up, shake,

gallops away, resting

rear

Horse Object (bucket) play:

2 http://www.youtube.com/watch?v=Zn7QiYSEcK4

mouth, push, circle,

231.68

0.56

0.03

resting rear

Horse Object (large ball)

1 http://www.youtube.com/watch?v=0EVmhqyCNfk

(young) play: mouth, push,

kicks up, circle, pick

$\begin{array}{lll}115.50 & 0.19 & 0.00\end{array}$

up

Foal Object (large ball)

play: resting rear,

299.60

1.05

0.00

push, circle, pick up

Horse Object (small ball)

play: pick up, shake,

23.09

0.36

0.00

carry, drop/toss, 


\begin{tabular}{|c|c|c|c|c|c|c|}
\hline Horse & Object (large ball) & & & & 1 & http://www.youtube.com/watch?v=VQa3w-6NbXs \\
\hline & $\begin{array}{l}\text { play: push, rear, to } \\
\text { and from }\end{array}$ & 77.79 & 0.17 & 0.00 & & \\
\hline Horse & Object (small ball) & & & & 1 & http://www.youtube.com/watch?v=TTfNrR6S_xk \\
\hline (small) & $\begin{array}{l}\text { play: mouth, push, } \\
\text { kick up, circle }\end{array}$ & 31.21 & 0.10 & 0.00 & & \\
\hline Horse & $\begin{array}{l}\text { Object (large ball) } \\
\text { play: push }\end{array}$ & 4.83 & 0.00 & 0.00 & 1 & http://www.youtube.com/watch?v=L-6f585jsCs \\
\hline Horse & $\begin{array}{l}\text { Object (small ball) } \\
\text { play: rear, pick up, } \\
\text { circle, shake, drops, } \\
\text { kicks up }\end{array}$ & 7.64 & 0.00 & 0.00 & 1 & http://www.youtube.com/watch?v=UXvLpXnuN30 \\
\hline Horse & $\begin{array}{l}\text { Object (small ball) } \\
\text { play: pick up, shake, } \\
\text { drop, push }\end{array}$ & 36.83 & 1.50 & 0.00 & 3 & http://www.youtube.com/watch?v=HowWTA6bhCg \\
\hline
\end{tabular}


647 Appendix 3. Use of iPads, iPods and iPhones by animals on YouTube.

\begin{tabular}{|c|c|c|c|c|c|c|}
\hline Animal & Descriptor & $\begin{array}{l}\text { Views/ } \\
\text { month }\end{array}$ & $\begin{array}{l}\text { Likes/ } \\
\text { month }\end{array}$ & $\begin{array}{l}\text { Dislikes } \\
\text { /month }\end{array}$ & $\begin{array}{l}\text { No. of } \\
\text { shots }\end{array}$ & URL \\
\hline \multirow[t]{2}{*}{ Dog } & Stepping, biting; response to contrast, & & & & 1 & http://www.youtube.com/watch?v= \\
\hline & movement or sound & $2,651.58$ & 10.16 & 0.16 & & Aump0K6TgHE \\
\hline \multirow[t]{2}{*}{ Dog } & Scratching; response to movement and & & & & 2 & http://www.youtube.com/watch?v= \\
\hline & contrast & 218.75 & 0.50 & 0.00 & & PPp4M3GoWUA \\
\hline \multirow[t]{2}{*}{ Dog } & Wary; response to contrast change, & & & & 1 & http://www.youtube.com/watch?v= \\
\hline & possible reflection & $108,538.91$ & 274.32 & 23.91 & & H3xdcx2WUcU \\
\hline \multirow[t]{2}{*}{ Dog } & Wary; response to contrast, movement & & & & 1 & http://www.youtube.com/watch?v= \\
\hline & or sound & 40.05 & 0.16 & 0.00 & & PwU9E5AZPa8 \\
\hline \multirow[t]{2}{*}{ Dog } & Nosing; response to movement and & & & & 1 & http://www.youtube.com/watch?v= \\
\hline & contrast & $8,365.00$ & 13.48 & 3.19 & & Ke-yiGYjzzY \\
\hline \multirow[t]{2}{*}{ Dog } & Scratching; response to movement and & & & & 1 & http://www.youtube.com/watch?v= \\
\hline & contrast & 97.88 & 0.88 & 0.00 & & jLffqYF_jGM \\
\hline Dog & Watching; response to movement, & 265.62 & 1.14 & 0.00 & 1 & http://www.youtube.com/watch?v= \\
\hline
\end{tabular}


Dog Scratching; response to bright toy, not

necessarily iPad

101.05

0.24

0.00

Dog Drinking; response to sound, reflectance of "water" (luminance)

Dog Licking; not really responding to iPad,

but simply to smooth surface

423.88

Stepping on iPad but to command;

response to command

146.95

Scratching; response to movement and

contrast

$2,605.00$

5.43

0.00

Dog

Barking; responding to sound

Scratching; response to movement and

contrast

112.00

0.00

Dog
1 http://www.youtube.com/watch?v= LRI6j53Zr_0

1 http://www.youtube.com/watch?v= XGk8Nu2KGoo

1 http://www.youtube.com/watch?v= tsuP6PRpntY

1 http://www.youtube.com/watch?v= jnNle0iKK1c

1 http://www.youtube.com/watch?v= 45C8XYQTpFQ

1 http://www.youtube.com/watch?v= SQGybLtdJds

1 http://www.youtube.com/watch?v= QjIg8ZGatxk

1 http://www.youtube.com/watch?v= iGtB8nX58PU 


\begin{tabular}{|c|c|c|c|c|c|c|}
\hline \multirow[t]{2}{*}{ Dog } & \multirow[t]{2}{*}{ Nosing; response to movement } & & & & 1 & http://www.youtube.com/watch?v= \\
\hline & & 8.11 & 0.06 & 0.00 & & U0u-s6rhEMo \\
\hline \multirow[t]{2}{*}{ Dog } & Watching; response to sound & & & & 2 & http://www.youtube.com/watch?v= \\
\hline & & 13.82 & 0.18 & 0.00 & & 0UqAT3VBEFA \\
\hline \multirow[t]{2}{*}{ Dog } & Licking; response to movement and & & & & 1 & http://www.youtube.com/watch?v= \\
\hline & contrast & 14.00 & 0.00 & 0.00 & & TzEFfokLipM \\
\hline \multirow[t]{2}{*}{ Dog } & Scratching; response to movement and & & & & 1 & http://www.youtube.com/watch?v= \\
\hline & contrast & 44.43 & 0.14 & 0.00 & & lksQdnh1DwM \\
\hline \multirow[t]{2}{*}{ Dog } & Scratching; response to movement and & & & & 1 & http://www.youtube.com/watch?v= \\
\hline & contrast & 86.77 & 1.00 & 0.00 & & cUoDk-YasMk \\
\hline \multirow[t]{2}{*}{ Dog } & Barking; responding to actual image & & & & 1 & http://www.youtube.com/watch?v= \\
\hline & & 19.57 & 0.00 & 0.00 & & 9qZoSC_ACz4 \\
\hline \multirow[t]{2}{*}{ Dog } & Head wagging; response to sound & & & & 1 & http://www.youtube.com/watch?v= \\
\hline & & 83.00 & 1.00 & 0.00 & & vHNTj19b8Ho \\
\hline \multirow[t]{2}{*}{ Dog } & Scratching; response to brightness & & & & 1 & http://www.youtube.com/watch?v= \\
\hline & & 23.50 & 0.00 & 0.00 & & c4YNFmacCQA \\
\hline Dog & Scratching; response to movement and & 17.50 & 0.50 & 0.00 & 1 & http://www.youtube.com/watch?v= \\
\hline
\end{tabular}


Dog Scratching; response to movement and

contrast

Dog Scratching; response to brightness and contrast

Dog

Scratching; response to movement and contrast

0.22

0.11

Dog Biting; response to movement and contrast

Barking; response to sound

Scratching; response to movement and contrast

0.00

Dragon Predatory behaviour toward stimuli

$$
33,169.00
$$

1.50

Dragon

Predatory behaviour toward stimuli
1 http://www.youtube.com/watch?v= mGnLZRXp-U0

1 http://www.youtube.com/watch?v= 2MY5qCy_mM

1 http://www.youtube.com/watch?v= SLE2VYURU1E

1 http://www.youtube.com/watch?v= Nf4cysyiobo

1 http://www.youtube.com/watch?v= ZbYSAesn6UA

1 http://www.youtube.com/watch?v= zefkFB5Uq0U

1 http://www.youtube.com/watch?v= w09ZBiuE-78

1 http://www.youtube.com/watch?v= OflpX1CwStI 


\begin{tabular}{|c|c|c|c|c|c|c|}
\hline \multirow[t]{2}{*}{ Dragon } & Predatory behaviour toward stimuli & & & & 1 & http://www.youtube.com/watch?v= \\
\hline & & 363.00 & 1.00 & 0.00 & & PUWBWt-rAU0 \\
\hline \multirow[t]{2}{*}{ Dragon } & Predatory behaviour toward stimuli & & & & 1 & http://www.youtube.com/watch?v= \\
\hline & & $1,213.00$ & 2.00 & 0.00 & & dClfcMas6FY \\
\hline \multirow[t]{2}{*}{ Dragon } & Predatory behaviour toward stimuli & & & & 1 & http://www.youtube.com/watch?v= \\
\hline & & 367.00 & 1.00 & 0.00 & & pnP-0Axrk_M \\
\hline \multirow[t]{2}{*}{ Dragon } & Predatory behaviour toward stimuli & & & & 1 & http://www.youtube.com/watch?v= \\
\hline & & 556.00 & 2.50 & 0.00 & & Y2ZyqLA40Bo \\
\hline \multirow[t]{2}{*}{ Dragon } & Predatory behaviour toward stimuli & & & & 1 & http://www.youtube.com/watch?v= \\
\hline & & $1,241.00$ & 0.00 & 0.00 & & SbfxQt3XIts \\
\hline \multirow[t]{2}{*}{ Dragon } & Predatory behaviour toward stimuli & & & & 1 & http://www.youtube.com/watch?v= \\
\hline & & $1,701.50$ & 18.00 & 0.00 & & VudH5AYewGI \\
\hline \multirow[t]{2}{*}{ Dragon } & Predatory behaviour toward stimuli & & & & 1 & http://www.youtube.com/watch?v= \\
\hline & & 83.00 & 0.00 & 0.00 & & rjmT47E_0oA \\
\hline \multirow[t]{2}{*}{ Gecko } & Predatory behaviour toward stimuli & & & & 1 & http://www.youtube.com/watch?v= \\
\hline & & 250.22 & 1.61 & 0.00 & & 75zqD_SvX2E \\
\hline Chameleon & Aggression, possibly toward reflection & $2,042,939.30$ & $6,790.40$ & $1,042.50$ & 1 & http://www.youtube.com/watch?v= \\
\hline
\end{tabular}


6FWUjJF1ai0

Toad Predatory behaviour toward stimuli

$94,654.00$

Bonobo Tactile exploratory behaviour

$\begin{array}{lll}3,454.69 & 6.31 & 0.06\end{array}$

Chimp Watching; possibly curious of self image

Monkey Tactile exploratory behaviour

$26,083.29$

Monkey Tactile exploratory behaviour

\section{$51,923.86$}

Parrot Biting; response to movement and

(African contrast

grey)

Parrot Licking; tactile exploratory behaviour

(African

grey)
576.00

4.50

275.67

1.33

0.00

1

http://www.youtube.com/watch?v= MrYqba6jj10

1 http://www.youtube.com/watch?v= 4frWWPuvmWE

1 http://www.youtube.com/watch?v= SLWyUBvCv7M

1 http://www.youtube.com/watch?v= _xQNp8iMUqk

1 http://www.youtube.com/watch?v= 2Rn-rHQfVEM

1 http://www.youtube.com/watch?v= Q_xeezIGbsg

$\begin{array}{lll}133.00 & 0.67 & 0.00\end{array}$

1 http://www.youtube.com/watch?v= oi_00wdXGGE 


\begin{tabular}{|c|c|c|c|c|c|c|}
\hline Parrot & Biting; response to contrast; exploratory & & & & 1 & http://www.youtube.com/watch?v= \\
\hline (budgerigar) & behaviour & 146.95 & 0.30 & 0.05 & & dSNUn4f1c5k \\
\hline Parrot & Watching; exploratory behaviour toward & & & & 2 & http://www.youtube.com/watch?v= \\
\hline (budgerigar) & movement and contrast & 29.57 & 0.14 & 0.07 & & mUHD852z5kU\&feature=related \\
\hline Parrot & Pecking; response to contrast change, & & & & 1 & http://www.youtube.com/watch?v= \\
\hline (cockatiel)) & possibly sound and reflection & 29.60 & 0.27 & 0.00 & & Pu7bF72qja8\&feature=related \\
\hline Parrot & Licking; exploratory behaviour & & & & 1 & http://www.youtube.com/watch?v= \\
\hline (cockatoo) & & 92.50 & 0.50 & 0.00 & & kF605jzoojo \\
\hline Parrot & Licking and pecking; exploratory & & & & 1 & http://www.youtube.com/watch?v= \\
\hline (cockatoo) & behaviour & 99.00 & 0.00 & 0.00 & & CYq9MR73HOI \\
\hline \multirow[t]{2}{*}{ Cat } & Directed visual tracking and pawing & & & & 1 & http://www.youtube.com/watch?v= \\
\hline & (predatory/play behaviour) & $406,212.09$ & 1603.57 & 26.30 & & Q9NP-AeKX40 \\
\hline \multirow[t]{2}{*}{ Cat } & Directed visual tracking and pawing & & & & 1 & http://www.youtube.com/watch?v= \\
\hline & (predatory/play behaviour) & $529,874.00$ & 2237.00 & 26.33 & & CdEBgZ5Y46U \\
\hline \multirow[t]{2}{*}{ Cat } & Directed visual tracking and pawing & & & & 1 & http://www.youtube.com/watch?v= \\
\hline & (predatory/play behaviour) & $30,985.13$ & 85.53 & 0.87 & & 36Jb3VhwK00 \\
\hline Cat & Directed visual tracking and pawing & $8,863.09$ & 5.30 & 1.52 & 1 & http://www.youtube.com/watch?v= \\
\hline
\end{tabular}


Cat

Directed visual tracking and pawing

(predatory/play behaviour)

Cat Directed visual tracking and pawing

(predatory/play behaviour)

Cat

Directed visual tracking and pawing

(predatory/play behaviour)

$44,510.71$

60.71

0.86

Cat

Directed visual tracking and pawing

(predatory/play behaviour)

$27,613.83$

11.61

Cat Directed visual tracking and pawing

(predatory/play behaviour)

$7,101.00$

117.75

2.75

Cat

Directed visual tracking and pawing

(predatory/play behaviour)

459.14

0.68

0.05

Cat Directed visual tracking and pawing

(predatory/play behaviour)

255.08

Directed visual tracking and pawing

(predatory/play behaviour)
1 http://www.youtube.com/watch?v= KTY9ugvTZo4

1 http://www.youtube.com/watch?v= p70wRQ4ANAA

1 http://www.youtube.com/watch?v= bSnmnqLaoQg

1 http://www.youtube.com/watch?v= tyO-KiYIDm0

1 http://www.youtube.com/watch?v= 8CDPxc647GQ

1 http://www.youtube.com/watch?v= fGZqcgHRG78

1 http://www.youtube.com/watch?v= ehhTGTmYPQs

1 http://www.youtube.com/watch?v= 6BfaL8xhsGM 


\begin{tabular}{|c|c|c|c|c|c|c|}
\hline Cat & $\begin{array}{l}\text { Directed visual tracking and pawing } \\
\text { (predatory/play behaviour) }\end{array}$ & 122.47 & 0.73 & 0.00 & 1 & $\begin{array}{l}\text { http://www.youtube.com/watch?v= } \\
\text { 6R3djChWqQo }\end{array}$ \\
\hline Cat & $\begin{array}{l}\text { Directed visual tracking and pawing } \\
\text { (predatory/play behaviour) }\end{array}$ & $4,009.65$ & 11.13 & 0.48 & 2 & $\begin{array}{l}\text { http://www.youtube.com/watch?v= } \\
\text { w64XRIYvBGk }\end{array}$ \\
\hline Cat & $\begin{array}{l}\text { Directed visual tracking and pawing } \\
\text { (predatory/play behaviour) }\end{array}$ & 293.33 & 3.33 & 0.67 & 1 & $\begin{array}{l}\text { http://www.youtube.com/watch?v= } \\
\text { 7NDWH5b-1iA }\end{array}$ \\
\hline Cat & $\begin{array}{l}\text { Directed visual tracking and pawing } \\
\text { (predatory/play behaviour) }\end{array}$ & 396.20 & 3.10 & 0.10 & 1 & $\begin{array}{l}\text { http://www.youtube.com/watch?v= } \\
\text { 9-K9WSQKGMQ }\end{array}$ \\
\hline Cat & $\begin{array}{l}\text { Directed visual tracking and pawing } \\
\text { (predatory/play behaviour) }\end{array}$ & $2,828.47$ & 6.93 & 0.13 & 1 & $\begin{array}{l}\text { http://www.youtube.com/watch?v= } \\
\text { YKr33bXOPns }\end{array}$ \\
\hline Cat & $\begin{array}{l}\text { Directed visual tracking and pawing } \\
\text { (predatory/play behaviour) }\end{array}$ & $17,752.10$ & 50.40 & 0.20 & 1 & $\begin{array}{l}\text { http://www.youtube.com/watch?v= } \\
\text { 8mGpL2LNo4s }\end{array}$ \\
\hline Cat & $\begin{array}{l}\text { Directed visual tracking and pawing } \\
\text { (predatory/play behaviour) }\end{array}$ & $3,654.93$ & 5.47 & 0.13 & 1 & $\begin{array}{l}\text { http://www.youtube.com/watch?v= } \\
\text { 2Y78Xq3-nMQ }\end{array}$ \\
\hline Cat & $\begin{array}{l}\text { Directed visual tracking and pawing } \\
\text { (predatory/play behaviour) }\end{array}$ & 208.67 & 0.27 & 0.00 & 1 & $\begin{array}{l}\text { http://www.youtube.com/watch?v= } \\
\text { B0iMQXiP-H8 }\end{array}$ \\
\hline Cat & Directed visual tracking and pawing & 178.80 & 0.90 & 0.00 & 1 & http://www.youtube.com/watch?v= \\
\hline
\end{tabular}


(predatory/play behaviour)

Cat

Directed visual tracking and pawing

(predatory/play behaviour)

Cat Directed visual tracking and pawing

(predatory/play behaviour)

Cat Scratching; response to apparent

movement

Cat

Directed visual tracking and pawing

(predatory/play behaviour)

Cat Directed visual tracking and pawing

(predatory/play behaviour)

76.40

$4,621.59$

8.91

0.18

(predatory/play behaviour)

Cat Directed visual tracking and pawing

(predatory/play behaviour)

753.20

Cat
Directed visual tracking and pawing

(predatory/play behaviour)
1 http://www.youtube.com/watch?v= _iC2kf_1qnM

1 http://www.youtube.com/watch?v= 0J9Lty4ZBA4

1 http://www.youtube.com/watch?v= iNzNjTR8074

1 http://www.youtube.com/watch?v= SN19TYZdYBE

1 http://www.youtube.com/watch?v= e8h8VK7cvJY

3 http://www.youtube.com/watch?v= vHlflwpBgnU

1 http://www.youtube.com/watch?v= wUOkde_lsLY

2 http://www.youtube.com/watch?v= 9wck3dsp8iQ 


\begin{tabular}{|c|c|c|c|c|c|c|}
\hline \multirow[t]{2}{*}{ Cat } & Directed visual tracking and pawing & & & & 1 & http://www.youtube.com/watch?v= \\
\hline & (predatory/play behaviour) & 59.43 & 0.57 & 0.00 & & MUfeEElBvkA \\
\hline \multirow[t]{2}{*}{ Cat } & Directed visual tracking and pawing & & & & 1 & http://www.youtube.com/watch?v= \\
\hline & (predatory/play behaviour) & $533,377.67$ & 2242.00 & 26.67 & & CdEBgZ5Y46U\&feature=fvst \\
\hline \multirow[t]{2}{*}{ Cat } & Directed visual tracking (predatory/play & & & & 1 & http://www.youtube.com/watch?v= \\
\hline & behaviour) & $4,408.50$ & 4.67 & 3.17 & & PM04Yc8vslg \\
\hline \multirow[t]{2}{*}{ Cat } & Directed visual tracking and pawing & & & & 1 & http://www.youtube.com/watch?v= \\
\hline & (predatory/play behaviour) & 62.33 & 0.13 & 0.00 & & bTxtx4eT9lI \\
\hline \multirow[t]{2}{*}{ Cat } & Directed visual tracking and pawing & & & & 3 & http://www.youtube.com/watch?v= \\
\hline & (predatory/play behaviour) & 516.89 & 3.00 & 0.11 & & srblsSYFOR4 \\
\hline \multirow[t]{2}{*}{ Cat } & Directed visual tracking and pawing & & & & 1 & http://www.youtube.com/watch?v= \\
\hline & (predatory/play behaviour) & $2,526.59$ & 3.06 & 0.18 & & 3QVqtmT0tdM \\
\hline \multirow[t]{2}{*}{ Cat } & Directed visual tracking and pawing & & & & 1 & http://www.youtube.com/watch?v= \\
\hline & (predatory/play behaviour) & $4,734.50$ & 4.36 & 0.09 & & bvNxF0sge88 \\
\hline \multirow[t]{2}{*}{ Cat } & Directed visual tracking and pawing & & & & 1 & http://www.youtube.com/watch?v= \\
\hline & (predatory/play behaviour) & $7,392.00$ & 1.10 & 0.10 & & pkJ5vIIunzk \\
\hline Cat & Directed visual tracking and pawing & 372.80 & 0.40 & 0.07 & 1 & http://www.youtube.com/watch?v= \\
\hline
\end{tabular}


Cat

Directed visual tracking and pawing

(predatory/play behaviour)

197.60

1.33

0.00

Cat Directed visual tracking and pawing

(predatory/play behaviour)

200.90

Directed visual tracking and pawing

(predatory/play behaviour)

$1,011.17$

2.43

0.04

Cat

Directed visual tracking and pawing

(predatory/play behaviour)

282.43

0.86

0.43

Cat Directed visual tracking and pawing

(predatory/play behaviour)

75.35

0.40

0.00

Cat

Directed visual tracking and pawing

(predatory/play behaviour)

221.46

0.85

0.00

Cat Directed visual tracking and pawing

(predatory/play behaviour)

167.41

0.00

Cat
Directed visual tracking and pawing

(predatory/play behaviour)
26.36
1 http://www.youtube.com/watch?v= UMQqvpYC4oA

2 http://www.youtube.com/watch?v= zWqRX-EtXzg

1 http://www.youtube.com/watch?v= XSJg4DYLxb0

1 http://www.youtube.com/watch?v= DQ4JcDexzTo

1 http://www.youtube.com/watch?v= Mhvv_mcw00A

1 http://www.youtube.com/watch?v= ltGDLgj2jo4

2 http://www.youtube.com/watch?v= yqgWaD3cy6M

1 http://www.youtube.com/watch?v= 2ewheCIEeVg 


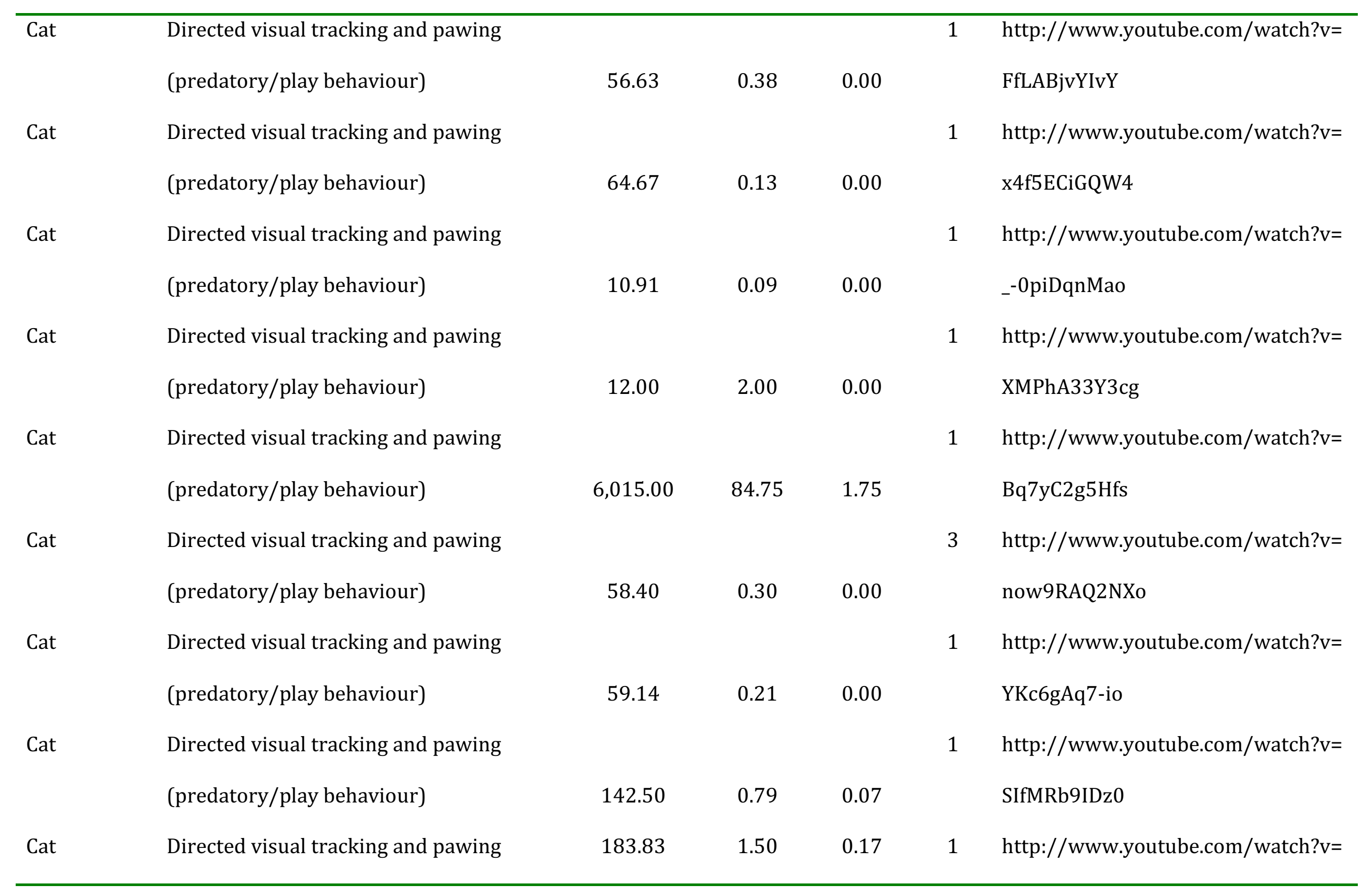


Cat

Directed visual tracking and pawing

(predatory/play behaviour)

Cat

Directed visual tracking and pawing

(predatory/play behaviour)

Cat Directed visual tracking and pawing

(predatory/play behaviour)

Directed visual tracking and pawing

(predatory/play behaviour)

Cat Directed visual tracking and pawing

(predatory behaviour)

Cat

Directed visual tracking and pawing

(predatory/play behaviour)

$1,655.00$

Cat Directed visual tracking and pawing

(predatory/play behaviour)

Cat

Licking; response to unmoving image
49.10

0.10

0.00

1.00

0.00

1.00

0.00

12.00

0.00

610.00

41.00

1.00

3 http://www.youtube.com/watch?v= vHlflwpBgnU

1 http://www.youtube.com/watch?v= bzyO2hOqCFg

1 http://www.youtube.com/watch?v= V53yolQaBig

1 http://www.youtube.com/watch?v= TQfk2z2xhHQ

1 http://www.youtube.com/watch?v= s-Yl9Ycy-WQ

1 http://www.youtube.com/watch?v= v2ELm6w86n4

1 http://www.youtube.com/watch?v= cE97Gy1UIH0

1 http://www.youtube.com/watch?v= 
